\title{
Belirtme Durumu Çekiminin Kommunist Gazetesi Örneğinde Sovyet Dönemi Azerbaycan Türkçesindeki Değişimi ve Bu Değişimde SSCB'nin Dil Planlaması Politikasının Etkisi
}

\author{
DOÇ. DR. MUSTAFA KARATAŞ* - MERVE KARADUMAN**
}

\section{Öz}

Türk dilinin durum çekimlerinden biri olan belirtme durumu, ekli (+I) veya eksiz (Ø) olmak üzere iki biçimde gerçekleşir. Ekli belirtme durumu çekiminin, Türk yazı dillerinde farklı ses ve biçim özellikleriyle kullanıldı̆̆ 1 görülmektedir.

Eski Türkçe döneminde ana hatlarıyla ortak bir biçimde yapılan bu çekimin, 11. yüzyıldan itibaren doğu, kuzey ve batı bölgelerindeki üç farklı coğrafyada gelişimini sürdüren Türk yazı dili geleneklerinde farklı biçimbirimlerle yapıldı̆̆ı görülmektedir. Bu farklılıkların görüldüğü kollardan biri de Oğuzcadır. Batı Oğuzcanın doğu kolunu oluşturan Azerbaycan Türkçesinin tarihî gelişim sürecinde de bu çekimin biçimbirimlerinde çeşitli değişimler görülmektedir. Bu değişimler, özellikle farklı alfabelerin kullanıldı̆̆ 1 Sovyet Dönemi Azerbaycan basınına da açık bir biçimde yansımıştır.

Azerbaycan Komünist Parti Merkezi Komitesinin yayın organı olması nedeniyle Sovyet Dönemi Azerbaycan Türkçesinin en önemli gazetesi olan Kommunist gazetesi, 29 Ağustos 1919-27 Ağustos 1991 tarihleri arasında Arap, Latin ve Kiril olmak üzere üç farklı alfabede yayımlanmıştır. $\mathrm{Bu}$ özelliği nedeniyle, Azerbaycan Türkçesindeki ses ve yazım değişimlerinin incelenebilmesi açısından büyük bir öneme sahiptir. Bu açıdan bakıldığında özellikle Oğuz Türkçesinde belirgin değişimleri görülen belirtme durumu çekiminin gazetenin farklı alfabelerle yayımlanmış sayılarındaki örnekleri bu değişimin niteliğini açık bir biçimde göstermektedir. Ancak değişimin alfabelere göre farklılık göstermesi, değişimlerin doğal bir süreç içerisinde değil, SSCB'nin dil plânlaması politikası sonucunda olabileceğini düşündürmüştür.

Bu çalışmada, belirtme durumu çekiminin tarihî gelişimi, Azerbaycan Türkçesinin yazı dili olma sürecindeki değişimi, bu değişimin Arap, Latin ve Kiril harfli metinlerdeki görünümü Kommunist gazetesindeki farklı alfabelerle yayımlanmış metinler örneklemi üzerinde incelenmiş ve bu değişimlerin Azerbaycan ile Türkiye Türklüğünün kullandığı ortak yazı dilini ayırmaya yönelik politik dil planlamasının bir parçası olup olmadığı üzerinde durulmuştur.

Anahtar sözcükler: Azerbaycan Türkçesi, Türkçe/Türk dili, belirtme durumu, Kommunist gazetesi, SSCB'nin dil planlaması

\footnotetext{
* Nevşehir H. Bektaş Veli Ün. Fen-Edebiyat Fak. ÇTLE Böl. mustafakaratas@nevsehir.edu.tr, orcid: 0000-0002-8165-4166

** Nevşehir H. Bektaş Veli Ün. Sosyal Bil. Ens. ÇTLE Böl. merve.karaduman42@gmail.com, orcid: 0000-0002-8798-0704 


\title{
CHANGE OF THE ACCUSATIVE CASE INFLECTION AZERBAIJANI TURKISH IN THE SOVIET ERA IN THE SAMPLE OF KOMMUNIST NEWSPAPER AND THE EFFECT OF THE USSR LANGUAGE PLANNING POLICY OF ON THIS CHANGE
}

\begin{abstract}
As one of the Turkish case suffixes, accusative case is used in two forms as being with suffix (+I) or without suffix $(\varnothing)$. It is observed that the accusative case inflection with suffix is used with different phonetic and morphological features in Turkish written languages.

It is observed that this inflection, which was mainly made in a common way in the Old Turkic period, has been made with different morphemes in the Turkish written language traditions that have continued to develop in three different geographies in the eastern, northern and western regions since the 11th century. One of the branches where these differences are observed is Oghuz language. Various changes have been observed in the morphemes of this inflection in the historical development process of Azerbaijani Turkish, which is the eastern branch of Western Oghuz. These changes were clearly reflected in the Azerbaijani press, especially in the Soviet Era, where different alphabets were used.

Kommunist newspaper, which was the most important newspaper in Azerbaijani language in the Soviet Era as it was the media organ of the Azerbaijani Communist Party Central Committee, was published between August 29, 1919 and August 27, 1991 in three different alphabets as Arabic, Latin and Cyrillic. Due to this feature, it has a unique importance in terms of analysing the phonetic and spelling changes in Azerbaijani Turkish. Within this scope, examples of the accusative case inflection, which has significant changes especially in Oghuz language, in the issues of the newspaper published in different alphabets clearly show the nature of this change. However, the fact that the change varied by the alphabets made us consider that the changes may not have occurred in a natural process, but as a result of the language planning policy of the USSR.

In this study, the historical development of the accusative case inflection, the change in Azerbaijani Turkish's process of being a written language, and the appearance of this change in the texts with Arabic, Latin and Cyrillic letters were analysed on the sample of texts published in different alphabets in the Kommunist newspaper, and it was discussed whether these changes were a part of the political language planning to separate the common written language used by the people of Azerbaijan and Turkey.
\end{abstract}

Keywords: Azerbaijani Language, Turkish/Turkic language, Accusative Case, Kommunist newspaper, language planning of the USSR

\section{GİRIŞ}

- nsanın temel iletişim aracı olan dil sistemi, sadece nesne, varlık veya kavramların adlarından ibaret değildir. Bu adların varlığı, o dili kullanan insanların bilgi birikimlerini ifade eder. Bu da o dilin sözlük bilgisidir. Ancak dil sistemi sadece sözlükten oluşmaz. Dildeki söz varlığını oluşturan isim ve fiillerin çeşitli biçimlerde birbirlerine bağlanarak geçici ilişkiler kurmalarıyla sistem işlemeye başlar ve dil ortaya çıar.

Türkçe dil bilgisinde çekim adı verilen isimlerin ve fiillerin arasındaki bu ilişki, "Fiillerde kip, zaman, tarz, şahıs, sayı; isim soylu kelimelerde çokluk, iyelik ve isimlerin birbiriyle ilişkilerini belirleyen hal kavramını göstermek için eklerin getirilmesi" şeklinde (Korkmaz, 1992, s. 36), dil biliminde ise "sözlükbirimin bulunduğu yap içinde sözcük-biçimlerini yaratma süreci" (İmer vd. 2011, s. 72) şeklinde 
tanımlanmaktadır. Karaağaç'ın da "nedensiz ve sosyal genellemeleri ifade eden sözlük birimlerini bir araya getirerek onlardan nedenli ve bireysel özellemeler yapmak" (2013, s. 223) şeklinde tanımladığı çekim kavramını gerçekleştiren eklere ise çekim ekleri adı verilir. Türk dilinde çekim ekleri "isim çekim ekleri" ve "fiil çekim ekleri" olmak üzere ikiye ayrılır ve bu çekimler dilde söz dizimini oluşturur.

Türk dilinin durum (hâl) çekimlerinden biri olan belirtme durumu ${ }^{1}$ ekli veya eksiz (Ø) olmak üzere iki biçimde gerçekleşir. Bu çekimin görevi; ismi, arasında ilişki kurduğu ve kendisini etkileyen geçişli bir fiile bağlamak ve dilimizde belirlilik durumunu yerine getirmektir (Korkmaz, 2017, s. 112). Belirtme durumu eki, Türk dili tarihinde farklı yazı dillerinde farklı ses ve biçim özellikleriyle kullanılmıştır.

Bu çalışmada, belirtme durumu çekimini gerçekleştiren eklerin eski ve çağdaş Türk lehçelerindeki ses ve biçim özellikleri üzerinde kısaca durulmuş, özellikle de çekimin Azerbaycan Türkçesinin yazı dili olma sürecindeki değişimi, bu değişimin Arap, Latin ve Kiril harfli metinlerdeki görünümü Azerbaycan Komünist Parti Merkezi Komitesi'nin yayın organı olması nedeniyle SSCB (Sovyet Sosyalist Cumhuriyetler Birliği) Dönemi'nin en önemli gazetesi olan Kommunist örneklemi üzerinde incelenmiştir.

\section{BELİRTME DURUMU ÇEKIMININ TARİHî VE ÇAĞDAŞ TÜRK LEHÇELERİNDEKİ}

\section{GELIŞiMi}

Eski Türkçe döneminde bütün Türk boyları tarafından ortak bir yazı dili olarak kullanılan Türkçe; birtakım siyasi, sosyal, kültürel değişimler ve en önemlisi İslamiyet'in kabulü ile 11. yy. sonrasında batıda Oğuz (Eski Anadolu/Türkiye) Türkçesi, kuzeyde Kıpçak Türkçesi, doğuda ise Karahanlı ve Harezm Türkçesi olmak üzere üç farklı (Oğuz, Kıpçak, Karluk) kola ayrılmıştır. Bunlardan Doğu Türkçesi tarihte Karahanlı, Harezm ve Çağatay Türkçeleriyle eserler vermiştir. Bu grubun günümüzdeki temsilcileri Özbek ve Uygur Türkçeleridir. Kuzey Türkçesi tarihte Mısır, Suriye, Altın Orda bölgelerinde Kıpçak Türkçesi ile eserler vermiştir. Söz konusu grubun günümüzdeki temsilcileri Kırım-Tatar Türkçesi, Karaçay-Balkar Türkçesi, Kumuk Türkçesi, Tatar Türkçesi, Başkurt Türkçesi, Kazak Türkçesi, Kırgız Türkçesi, Karakalpak Türkçesi, Nogay Türkçesi, Karaimce/Karay Türkçesi'dir. Batı Türkçesi tarihte Eski Anadolu Türkçesi ve Osmanlı Türkçesi ile eserler vermiştir. Bu grubun günümüzdeki temsilcileri ise Türkiye Türkçesi, Azerbaycan Türkçesi, Türkmen Türkçesi ve Gagavuz Türkçeleridir (Karataş, 2019, s. 170-173; 2020, s. $48-51)$.

Tarih boyunca üç farklı koldan eserler vermeye devam eden Türk dili, lehçeleri arasında birtakım ses, yazım, biçim, söz dizimi değişikliklerine uğramıştır. Bu değişimlerden biri de

\footnotetext{
1 Türkiye Türkçesiyle ilgili yapılan dil bilgisi çalışmalarında bu kavram için akuzatif, yükleme, $i$ hali vb. terimler de kullanılmaktadır. Azerbaycan Türkçesinde bu çekime tasirlik hal adı verilmektedir (Hüseynzadə, 2007, s. 49). Bu terimin diğer Türk lehçelerindeki karşılığ1 ise şunlardır: Tkm. yeñiş düşüm, Gag. gösterek hal, Özb. tuşum kelişigi, Uyg. çüşüm geliş, Tat. töşem kileşe, Bşk. töşöm kileş, Kmk. tüşüm padej tüşüm geliş, Krç.-Blk. tamamlawçu boluş, Nog. tüsîm kelîs, Kzk. tabıs septik, Krg. tabış cöndömösü, Alt. köstööçi kubultkış, Hks. körîmgî padej körîmgî hubulthıs, Tuv. onaarınıñ padeji (Naskali, 1997, s. 85).
} 
çalışmamıza konu olan belirtme durumu çekimidir. Bu çekim, Türk dili tarihinde farklı dönemlerde, farklı yazı dillerinde çeşitli biçimlerle kullanılmıştır.

Türkçede belirtme durumu çekimi Eski Türkçeden itibaren yalın isimler, iyelikli isimler ve zamirlerde farklı eklerle yapılagelmiştir. Söz konusu çekimde kullanılan eklerin tarihî ve çağdaş Türk lehçelerindeki gelişimi şu şekildedir: ${ }^{2}$

Eski Türkçede (Köktürk, Uygur) belirtme durumu çekimi için birden fazla ek bulunmaktadır (Erdal, 2004, s. 366; Gabain, 2007, s. 64; Tekin, 2016, s. 102-104; Ölmez, 2017, s. 52-53, 306, 312, 321; Ergin, 2016, s. 157-160, 165):

\begin{tabular}{|c|c|c|c|c|}
\hline & \multirow{2}{*}{\multicolumn{2}{|c|}{$\frac{\text { Köktürkçe }}{\text { Ekler }}$}} & \multicolumn{2}{|r|}{ Uygurca } \\
\hline & & & Ekler & Yazımları \\
\hline Yalın isim & $\begin{array}{l}\{+(X) g\} \\
\{+(X) \dot{g}\}\end{array}$ & $\begin{array}{l}\text { FrIr 'kişig' } \\
\text { (KT G6) } \\
\text { ১\33) ) 'bodunug' } \\
\text { (KT D2) }\end{array}$ & $\{+(\mathrm{I}) \mathrm{g}\}$ & 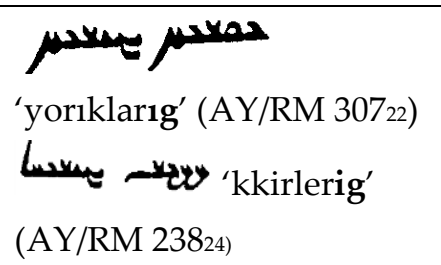 \\
\hline Iyelikli isim & $\{+(\mathrm{I}) \mathrm{n}\}$ & $\begin{array}{l}\text { Y১ßn' 'savımin' } \\
\text { (KT G2) } \\
\text { hrrNirN 'törösin' } \\
\text { (KT D1) }\end{array}$ & $\{+(\mathrm{I}) \mathrm{n}\}$ & 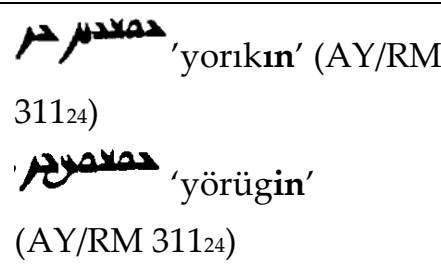 \\
\hline Zamir & $\{+n I\}$ & $\begin{array}{l}\text { ১〉) 'bon1' } \\
\text { (KT G12) }\end{array}$ & $\{+n I\}$ & 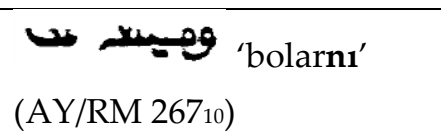 \\
\hline
\end{tabular}

11. yüzyıldan itibaren üç farklı coğrafyada gelişimini sürdüren Türk dili; doğu, kuzey ve batı bölgelerinde farklı yazı dili gelenekleriyle yüzlerce yıl eser vermeye devam etmiştir.

Doğu Türkçesi lehçelerinde belirtme durumu ekleri ve yazımları şu şekildedir:

\begin{tabular}{|l|l|l|}
\hline & \multicolumn{1}{|c|}{ Ekler } & \multicolumn{1}{|c|}{ Yazımları } \\
\hline Karahanlı Türkçesi $^{3}$ & $\{+(\mathrm{X}) \mathrm{g}\},\{(\mathrm{X})+\dot{\mathrm{g}}\}$, & $\{\dot{\varepsilon}\},\{$ s\} \\
& $\begin{array}{l}\{+\mathrm{nI}\} \\
\{+\mathrm{n}\}\end{array}$ & $\{\mathrm{v}\}$ \\
& $\{\dot{U}\}$ \\
\hline
\end{tabular}

\footnotetext{
2 Türkçenin tüm eklerinde olduğu gibi belirtme durumu çekiminde de ekin yapısındaki seslerin benzeşme süreçlerindeki farklılık ve ekin farklı ses özelliklerine sahip olması nedeniyle ek fonetik değişkeleriyle, yani biçimcikleriyle (İng. morph) kullanılmaktadır (Terim için bk. Uzun, 2006, s. 23). Çalışmada, bu biçimciklerin gösteriminde şu yöntem kullanılmıştır: Ekin hem düz hem yuvarlak ünlüden oluşan 4 değişkesi varsa ünlü yerine " $X$ " işareti, iki dar-düz ünlüden oluşan değişkesi varsa "I" işareti/harfi, iki dar-yuvarlak ünlüden oluşan değişkesi varsa " $U$ " işareti/harfi kullanılmıştır. Buna göre $\{+(y) X\}$ gösterimi $\{+(y) 1\},\{+(y) i\},\{+(y) u\},\{+(y) \ddot{u}\}$ biçimciklerini; $\{+n X\},\{+(n) 1\},\{+(n) i\},\{+n u\},\{+$ nü $\}$ biçimciklerini; $\{+X\}$ gösterimi $\{+1\},\{+i\},\{+u\},\{+\ddot{u}\} ;\{+(s) X(n) X\}$ ise $\{+\sin 1\},\{+\operatorname{sini}\},\{+$ sunu $\},\{+$ sünü $\},\{+$ nn $\},\{+i n i\},\{+u n u\},\{+u \ddot{n} \ddot{u}\}$ biçimciklerini ifade etmektedir.

${ }^{3}$ Argunşah, Sağol Yüksekkaya, 2017, s. 65, 87, 95, 110.
} 


\begin{tabular}{|c|c|c|c|}
\hline & $\{+I\}$ & \multicolumn{2}{|l|}{$s$} \\
\hline $\begin{array}{l}\text { Harezm Türkçesi } \\
\text { Çağatay Türkçesi }\end{array}$ & $\begin{array}{l}\{+\mathrm{nI}\} \\
\{+\mathrm{n}\} \\
\{+\mathrm{I}\}\end{array}$ & \multicolumn{2}{|l|}{$\begin{array}{l}\{\mathrm{\}}\} \\
\{\mathrm{\}}\} \\
\{\mathrm{\}}\}\end{array}$} \\
\hline \multirow[t]{2}{*}{ Özbek Türkçesi' ${ }^{6}$} & $\{+$ ni $\}$ & $\{$ \}ن & $\{+\mathrm{Hи}\}$ \\
\hline & $\{+n\}$ & $\{$ \} & $\{+\mathrm{H}\}$ \\
\hline $\begin{array}{l}\text { Yeni Uygur } \\
\text { Türkçesi }\end{array}$ & $\{+$ ni $\}$ & $\{$ \{ $\}$ & $\{+\mathrm{H} U\}$ \\
\hline
\end{tabular}

Kuzeyde ise Altın Orda, Mısır ve Suriye olmak üzere üç bölgede Kıpçak Türkçesiyle eserler verilmiştir. Belirtme durumu ekinin bu üç bölgedeki görünümü şu şekildedir:

\begin{tabular}{|l|l|l|}
\hline & \multicolumn{1}{|c|}{ Ekler } & \multicolumn{1}{|c|}{ Yazımları } \\
\hline Altın Orda $^{8}$ & $\{+n X\}$ & $\{$ ن $\}$ \\
& $\{+n\}$, & $\{\dot{ }\}$ \\
& $\{+\mathrm{I}\}$ & $\{\mathrm{s}\}$ \\
\hline Memluk $^{9}$ & $\{+\mathrm{nI}\}$ & $\{\mathrm{v}\}$ \\
\hline
\end{tabular}

Çağdaş Kıpçak lehçelerinde belirtme durumu eklerinin hem Arap hem de Kiril harfli yazımları görülmektedir:

\begin{tabular}{|c|c|c|c|}
\hline & Ekler & & Yazımları \\
\hline Kazak Türkçesi ${ }^{10}$ & $\begin{array}{l}\{+\mathrm{nI}\} \\
\{+\mathrm{dI}\} \\
\{+\mathrm{tI}\} \\
\{+\mathrm{n}\}\end{array}$ & $\begin{array}{l}\{\text { \{ }\} \\
\{\mathrm{S}\} \\
\{\text { \} }\} \\
\{\mathrm{U}\}\end{array}$ & $\begin{array}{l}\{+н ы\},\{+н и\} \\
\{+д ы\},\{+д и\} \\
\{+ \text { ты }\},\{+ \text { ти }\} \\
\{+ \text { +н }\}\end{array}$ \\
\hline Kırgız Türkçesi'11 & $\{+n X\}$ & \{نى & $\{-$ ны $\},\{-$ ни $\},\{-$ ну $\},\{-$ нү $\}$ \\
\hline
\end{tabular}

\footnotetext{
${ }^{4}$ Argunşah, Sağol Yüksekkaya, 2017, s. 192, 222, 249; Eckmann, 2014, s. 17.

${ }^{5}$ Eckmann, 2017, s. 73-74; Argunşah, 2020, s. 215, 224.

${ }^{6}$ Öztürk, 2012, s. 311; Ercilasun, 2014, s. 186-187; Coşkun, 2014, s. 239-242.

7 Yazıcı Ersoy, 2012, s. 377; Öztürk, 2015, s. 169-170.

${ }^{8}$ Hacieminoğlu, 1968, s. 52; Argunşah, Güler, 2015, s. 95.

${ }^{9}$ Karamanlığlu, 1989, s. 56; Argunşah, Sağol Yüksekkaya, 2017, s. 333, 362, 365.

${ }^{10}$ Tamir, 2012, s. 570; Doğan, Koç, 2013, s. 333-336; Ercilasun, 2014, s. 244-251.

${ }^{11}$ Kasapoğlu Çengel, 2012, s.508; 2017, s. 356-366; Ercilasun, 2014, s. 264-267.
} 


\begin{tabular}{|c|c|c|c|}
\hline $\begin{array}{l}\text { Karakalpak } \\
\text { Türkçesi }^{12}\end{array}$ & $\begin{array}{l}\{+\mathrm{d} X \\
\{+\mathrm{tX} \\
\{+\mathrm{n}\}\end{array}$ & $\begin{array}{l}\{\mathrm{f}\} \\
\{\mathrm{s}\} \\
\{\mathrm{U}\}\end{array}$ & $\begin{array}{l}\{-д ы\},\{-д и\},\{-д y\},\{-д ү\} \\
\{- \text { ты }\},\{-т i\},\{- \text { ту }\},\{-т Y\} \\
\{+H\}\end{array}$ \\
\hline Nogay Türkçesi ${ }^{13}$ & $\begin{array}{l}\{+\mathrm{nI}\} \\
\{+\mathrm{dI}\} \\
\{+\mathrm{tI}\} \\
\{+\mathrm{n}\}\end{array}$ & $\begin{array}{l}\{\mathrm{f}\} \\
\{\mathrm{S}\} \\
\{\mathrm{s}\} \\
\{\mathrm{\}}\}\end{array}$ & $\begin{array}{l}\{- \text {-ны }\},\{-н и\} \\
\{-д ы\},\{-д и\} \\
\{- \text {-лы\}, \{-ти\} } \\
\{+ \text { t- }\}\end{array}$ \\
\hline Tatar Türkçesi' ${ }^{14}$ & $\begin{array}{l}\{+n I\}^{15} \\
\{+n\}\end{array}$ & $\begin{array}{l}\{\text { \{ } \\
\{\text { (ن\} }\end{array}$ & $\begin{array}{l}\{+\mathrm{Hb}\},\{+\mathrm{He}\} \\
\{+\mathrm{H}\}\end{array}$ \\
\hline Kırım-Tatar Türkçesi' ${ }^{16}$ & $\{+\mathrm{nI}\}$ & $\{$ \{ن & $\{+$ ны $\},\{+$ +н $\}$ \\
\hline Başkurt Türkçesi ${ }^{17}$ & $\begin{array}{l}\{+n X\}^{18} \\
\{+d X\}^{19} \\
\{+t X\}^{20} \\
\{+z X\}^{21} \\
\{+n\}\end{array}$ & 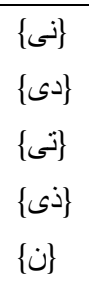 & 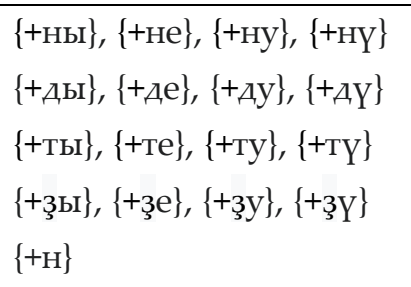 \\
\hline $\begin{array}{l}\text { Karaçay-Balkar } \\
\text { Türkçesi }^{22}\end{array}$ & $\begin{array}{l}\{+\mathrm{nX}\} \\
\{+\mathrm{X}\} \\
\{+\mathrm{n}\}\end{array}$ & $\begin{array}{l}\{\mathrm{f}\} \\
\{\mathrm{G}\} \\
\{\mathrm{U}\}\end{array}$ & $\begin{array}{l}\{+ \text { ны }\},\{+ \text { ни }\},\{+ \text { ну }\},\{+ \text { ню }\} \\
\{+ \text { I }\},\{+ \text { }\},\{+ \text { ну }\},\{+ю\} \\
\{+ \text { }\}\end{array}$ \\
\hline Kumuk Türkçesi ${ }^{23}$ & $\{+n X\}$ & $\{$ \}ن & $\begin{array}{l}\{+\mathrm{Hы}\},\{+ \text { +ни }\} \\
\{+\mathrm{Hy}\},\{+\mathrm{H} ю\}\end{array}$ \\
\hline Karay Türkçesi ${ }^{24}$ & $\begin{array}{l}\{+\mathrm{nI}\}^{25} \\
\{+\mathrm{I}\}\end{array}$ & $\begin{array}{l}\{\checkmark\} \\
\{\checkmark\}\end{array}$ & $\begin{array}{l}\{+ \text { ны }\},\{+ \text { ни }\}, \\
\{+ \text { +ну\}, \{+ню\} }\end{array}$ \\
\hline
\end{tabular}

12 Uygur, 2012, s. 570; Alkaya, Buran, 2014, s. 464-469.

${ }^{13}$ Ergönenç Akbaba, 2012, s. 635; Alkaya, Buran, 2014, s. 337-339.

14 Öner, 2012, s. 709; Ercilasun, 2014, s. 227-228; Alkaya, Buran, 2014, s. 80,85.

$15\{+n 1\},\{+$ ně $\}$

16 Yüksel, 2012, s. 845; Ercilasun, 2014, s. 214-215; Alkaya, Buran, 2014, s. 400.

17 Yazıcı Ersoy, 2012, s. 767; Alkaya, Buran, 2014, s. 275-277; Bulat, 1925.

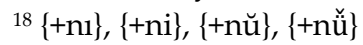

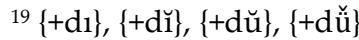

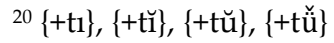

$21\{+z \underline{l}\},\{+z \breve{l}\},\{+z \breve{u}\},\{+z \breve{u}\}$

22 Tavkul, 2012, s. 905; Ercilasun, 2014, s. 238-241, Alkaya, Buran, 2014, s. 580-584.

${ }^{23}$ Pekacar, 2012, s. 977; Alkaya, Buran, 2014, s.521, 526, 531;

https:/til.im/tr-qm/knigi/literatura-na-kumykskom-yazyke/men-oktemmen?gesek=1 (erişim tarihi: 16.08.2021) ;http://kumukia.ru/\%D0\%BD\%D0\%BE\%D0\%B2\%D1\%8B\%D0\%B9-

\%D1\%80\%D0\%B5\%D1\%81\%D1\%83\%D1\%80\%D1\%814.html\#cf (erişim tarihi: 16.08.2021).

${ }^{24}$ Gülsevin, 2010, s. 103-105.

$25\{+n i\},\{+n u\},\{+n \ddot{u}\}$ 
Doğu ve Kuzey Türkçeleri dışında 11. yüzyıldan sonra Anadolu, Azerbaycan, İran ve Türkmenistan coğrafyalarında yazılı dil olarak gelişmeye başlayan Oğuz Türkçesinin (Batı Türkçesi, Güneybatı Türkçesi) ilk dönemini oluşturan Eski Anadolu Türkçesi (Eski Osmanlıca, Eski Oğuz Türkçesi, Eski Türkiye Türkçesi, Tarihi Türkiye Türkçesi) döneminde farklı bir gelişim çizgisi izlemiştir (Ergin, 2013, s. 231-232). Bu dönemde yaygın kullanılan belirtme durumu eki, ünsüzle biten tabanlara $\{+\mathrm{I}\}$ ünlüyle biten tabanlara $\{+(y) I\}$, ve teklik 3. şahıs iyelik ekinden sonra gelen $\{+(\mathrm{n}) \mathrm{I}\}$ biçimlerindedir. ${ }^{26}$

Eski Türkçede isimlerden sonra kullanılan $\{+(X) g\},\{+(X) \dot{g}\}$ ekindeki /-g/ ve /- $\dot{g} /$ seslerinin Batı Türkçesinde düşmesi sonucunda aradaki yardımcı ses /-I/ belirtme durumu ekinin işlevini üzerine alarak bu çekim için kullanılmaya başlamıştır. ${ }^{27}$ Bu dönemde nadir kullanılan belirtme durumu eki ise teklik 3. şahıs iyelik ekinin üzerine gelen \{+(I)n\}'dır (Gülsevin, 2017, s. 40-46; Akar, 2018, s. 138; Şahin, 2018, s. 50-51). Söz konusu dönemde kullanılan belirtme durumu eklerinden $\{+n I\}$, metinlerde nun ve ye harfleri $\{$ ن $\}$ ile; $\{+(\mathrm{I}) \mathrm{n}\}$ ye ve nun harfleri $\{\omega\}$ ile; $\{+\mathrm{I}\}$ eki ise $\{\boldsymbol{s}$ ye harfi ile yazılmıştır (Ergin, 2016, s. 4, 8).

Osmanlı Türkçesinde belirtme durumu çekimi için $\{+\mathrm{I}\}$ eki kullanılmaktadır. Bu dönemde kullanılan belirtme durumu eki olan $\{+\mathrm{I}\}^{\prime}$ nın metinlerde ye $\{\boldsymbol{s}\}$ harfi ile yazıldığ görülmektedir. Osmanlı Türkçesi dönemi başlarında dudak uyumu tam anlamıyla sağlanamamıştır. Belirtme durumu ekinin dudak uyumuna en son giren eklerden biri olduğu ve 18. yüzyılda dahi genellikle uyumsuz olduğu belirtilmektedir (Kartallığlu, 2011, s. 161-168). Bu durumun temel nedeni, bu ekin Eski Anadolu Türkçesinden itibaren Arap harflerinden ye \{ $s\}$ harfi ile yazılmış ve bu harfin de düz-dar ünlüler için kullanılmış olmasıdır (Ergin, 1998, s. 21; Kartallığlu, 2008, s. 467-468; Develi, 2014, s. 96). Ek, düzlük-yuvarlaklık uyumuna tam anlamıyla Türkiye Türkçesinde girmiştir.

Belirtme durumu ekinin Türkiye Türkçesi ve diğer Oğuz lehçelerindeki durumu şu şekildedir:

\begin{tabular}{|c|c|c|c|}
\hline & Ekler & & Yazımları \\
\hline Türkiye Türkçesi ${ }^{28}$ & $\begin{array}{l}\{+(\mathrm{y}) \mathrm{X}\} \\
\{+\mathrm{nI}\} \\
\{+\mathrm{n}\}\end{array}$ & $\begin{array}{l}\{\mathrm{G}\} \\
\{\mathrm{G}\} \\
\{\mathrm{U}\}\end{array}$ & $\begin{array}{l}\{+(\mathrm{y}) 1\},\{+(\mathrm{y}) \mathrm{i}\}\{+(\mathrm{y}) \mathrm{u}\}, \\
\{+(\mathrm{y}) \ddot{\mathrm{u}}\} \\
\{+\mathrm{n} \mathbf{\}},\{+\mathrm{ni}\} \\
\{+\mathrm{n}\}\end{array}$ \\
\hline $\begin{array}{l}\text { Azerbaycan } \\
\text { Türkçesi }^{29}\end{array}$ & $\begin{array}{l}\{+X\} \\
\{+n X\}^{30}\end{array}$ & $\begin{array}{l}\{\mathrm{f}\} \\
\{\mathrm{S}\}\end{array}$ & $\begin{array}{l}\{+1\},\{+\mathrm{i}\},\{+\mathrm{u}\},\{+\ddot{u}\} \\
\{+n 1\},\{+n i\},\{+n u\},\{+n \ddot{u}\}\end{array}$ \\
\hline Türkmen Türkçesi ${ }^{31}$ & $\begin{array}{l}\{+\mathrm{nI}\} \\
\{+\mathrm{X}\}\end{array}$ & $\begin{array}{l}\{\checkmark\} \\
\{\checkmark\}\end{array}$ & $\begin{array}{l}\{+\mathrm{H}\},\{+ \text { ни } \\
\{+\mathrm{I}\}\{+\mathrm{\}}\}\end{array}$ \\
\hline
\end{tabular}

\footnotetext{
${ }^{26}$ Gülsevin, 1997, s. 31-36. EAT metinlerinde yalın, yönelme ve ayrılma hali eklerinin de belirtme hali işlevinde kullanıldığ görülebilmektedir: s. 35-36.

${ }^{27}$ ET. -1-g > EAT. -1 biçiminde kabul edilen gelişmenin eleştirisi için bk. Mansuroğlu, 1949, s. 505, Canpolat, 1992, s. 9-11.

${ }^{28}$ Ergin, 2013, s. 231-233; Korkmaz, 2017, s. 291-292.

${ }^{29}$ Mirzəzadə, 1990, s. 44-46; Hüseynzadə, 2007, s. 49-51; Kazımov, 2010, s. 73-78.

30 Azerbaycan Türkçesinde belirtme durumu çekiminin gelişimi ve yazımı ayrıntılı bir şekilde inceleneceği için bu bölümde genel bilgi verilerek geçilmiştir.

${ }^{31}$ Kara, 2012, s. 257; Ercilasun, 2014, s. 174-175; Alkaya, Buran, Yalçın, 2017, s. 215-219; Seỳtäkov, 1972, s. 7-12.
} 


\begin{tabular}{|l|l|l|l}
\hline Gagavuz Türkçesi $^{32}$ & $\{+(\mathrm{y}) \mathrm{X}\}$ & $\{\mathrm{s}\}$ & $\begin{array}{l}\{+\mathrm{m}\},\{+\mathrm{n}\} \\
\{+\mathrm{y}\}\{+\ddot{\mathrm{y}}\}\end{array}$ \\
\hline
\end{tabular}

Belirtme durumu çekiminde Kuzeydoğu (Sibirya) grubu Türk lehçelerinde kullanılan ekler ve yazımları ise şu şekildedir:

\begin{tabular}{|c|c|c|}
\hline & Ekler & Yazımları \\
\hline Altay Türkçesi ${ }^{33}$ & $\begin{array}{l}\{+\mathrm{nI}\} \\
\{+\mathrm{dI}\} \\
\{+\mathrm{tI}\}\end{array}$ & $\begin{array}{l}\{+ \text { +ны }\},\{+н и\} \\
\{+д ы\},\{+д и\} \\
\{+ \text { ты }\},\{+ \text { ти }\}\end{array}$ \\
\hline Hakas Türkçesi ${ }^{34}$ & $\begin{array}{l}\{+\mathrm{nI}\}^{35} \\
\{+\mathrm{t}\}^{36} \\
\{+\mathrm{I}\}^{37} \\
\{+\mathrm{n}\}\end{array}$ & 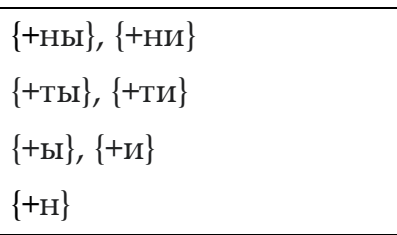 \\
\hline Tuva Türkçesi ${ }^{38}$ & $\begin{array}{l}\{+\mathrm{nX}\} \\
\{+\mathrm{d} X\} \\
\{+\mathrm{t} X\}\end{array}$ & 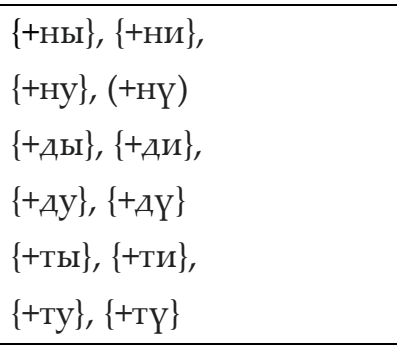 \\
\hline Saha Türkçesi ${ }^{39}$ & $\begin{array}{l}\{+X\} \\
\{+n X\} \\
\{+\mathrm{t} X\}\end{array}$ & $\begin{array}{l}\{+\mathrm{d}\},\{+\mathrm{\}}\},\{+\mathrm{y}\},\{+\gamma\} \\
\{+\mathrm{H}\},\{+\mathrm{H} и\},\{+\mathrm{Hy}\},\{+\mathrm{H} Y\} \\
\{+ \text { ты }\},\{+ \text { ти }\},\{+ \text { ту }\},\{+ \text { тү }\}\end{array}$ \\
\hline
\end{tabular}

Bulgar grubu Türk lehçesi olan Çuvaş Türkçesinde belirtme durumu çekiminde, yönelme durumu eki olan $\{+A\}$ kullanılmakta ve Kiril alfabesiyle de $\{+A\}$ şeklinde yazılmaktadır (Ersoy, 2018, s. 31).

\section{SOVYET DÖNEMİ AZERBAYCAN TÜRKÇESİ VE KOMMUNİST GAZETESİ}

Oğuz Türklerinin 11. yüzyıldan itibaren batıya doğru son göçü, başta Maveraünnehir, İran ve Kars'a girmeleriyle başlamış, 1071'den itibaren de Anadolu'nun fethiyle devam etmiştir. Bu göçlerin sonucunda, Anadolu ve Azerbaycan ikinci bir Türk yurduna dönüşmüştür. Bu göçlerin en önemli sonucu ve etkisi dil üzerinde görülmüş, Oğuz Türkçesi Anadolu, Kuzey ve Güney Azerbaycan, Irak, Suriye ve 14. yüzyılın ikinci yarısından itibaren de Balkanlar olmak üzere geniş bir coğrafyada kullanılan yazı dili hâline gelmiştir (Uğurlu, 201, s. 124-127).

Türk dili tarihinde Oğuz Türkçesinin ilk dönemini, Eski Osmanlıca, Eski Osmanlı Türkçesi, Eski Türkiye Türkçesi ve Anadolu Merkezli Oğuz Türkçesi adlarıyla da kullanılan Eski Anadolu Türkçesi oluşturmaktadır. Bu dönemin dili, özellikle ses ve yazımda tutarsızlıkların görüldüğü, aynı

32 Özkan, 2012, s. 114; Ercilasun, 2014, s. 122-123; Alkaya, Buran, Yalçın, 2017, s. 276-278.

33 Alkaya, Buran, Özeren, 2014, s. 61, 98, 105.

${ }^{34}$ Alkaya, Buran, Özeren, 2014, s. 127, 165, 173, 174.

$35\{+\mathrm{n} 1\},\{+\mathrm{n \breve {1 }}\}$

$36\{+\mathrm{t} 1\},\{+\mathrm{t} \breve{1})$

$37\{+1\},\{+\breve{1}\}$

${ }^{38}$ Alkaya, Buran, Özeren, 2014, s. 245-256.

${ }^{39}$ Kirişçioğlu, 2018, s. 131, 178-181. 
görevler için birbirinden farklı eklerin kullanıldığı, henüz ölçünlüleşmemiş bir yazı dilidir (Uğurlu, 2011, s. 130-132; Akar, 2018, s. 35-41). Söz konusu dilin yazı dili olarak kullanılmaya başladığı 11-15. yüzyıllarda, Azerbaycan sahası ve Osmanlı sahası arasında belirgin farklılıklar görülmeye başlamış ve bu durum Türklük biliminde "genel temayül, koyulaşma ve körlenme" adı verilen bir görüşle ifade edilmiştir. Bu görüşe göre, 18. yüzyılda Azerbaycan Türkçesi ve Osmanlı Türkçesi birbirinden tamamen ayrılmış ve ayrı iki yazı dili oluşturmuşlardır (Dilaçar, 1957, s. 8285).

Batı Türkçesinin çağdaş lehçelerinden biri olan Azerbaycan Türkçesi; Doğu Anadolu, Güney Kafkasya ve Kafkas Azerbaycan'1, İran Azerbaycan'1, Kerkük ve Irak-Suriye Türkleri coğrafyalarında kullanılmaktadır. Azerbaycan Türkçesinin oluşum ve gelişim süreci öncelikli olarak Azerbaycan coğrafyasının Türkleşmesiyle ilgili bir durumdur. Azerbaycan bölgesinin Türkleşme süreci özetle şu şekilde olmuştur:

11 ve 13. yüzyıllar arasında pek çok Oğuz boyunun Anadolu'ya yoğun bir şekilde göç etmesiyle birlikte Anadolu, bugünkü Kuzey ve Güney Azerbaycan, Irak (Kerkük), Suriye ve İran (Tebriz) bölgelerine yerleşmeye başlamış ve bu coğrafyalarda Oğuz ağız özelliklerini yaşatma sürecine girmişlerdir. Bu sürecin ardından birtakım sebeplerden dolayı kullanılan Oğuz ağızlarında ayrışmalar meydana gelmeye başlamış ve bu ayrışmaların 16 . yüzyılda tamamlanmasıyla birlikte Azerbaycan Türkçesi bugünkü çağdaş kimliğini kazanmıştır (Ergin, 197, s. 7-8).

Oğuz Türkçesinin doğu kolu olarak günümüze kadar gelişimini sürdüren Azerbaycan Türkçesinin üzerinde 19. yüzyılın ilk çeyreğinden sonra başlayan siyasi baskı, SSCB döneminden itibaren 20. yüzyılın sonlarına kadar etkisini göstermeye devam etmiştir. Tarihte yaygın olarak Sovyet Dönemi biçiminde adlandırılan bu dönem, Çarlık'ın devrildiği Bolşevik/Sovyet Devrimi (1917) ile başlayan ve 1991'de Sovyetler Birliği'nin dağılmasıyla sona eren dönemin genel adıdır.

Türkistan coğrafyasında 1552'de başlayan Rus işgali sonucunda egemenliği eline alan Ruslar, 1917'den sonra SSCB döneminde, özellikle de Josef Stalin'in (1878-1953) yönetimi ele almasıyla Sovyetler Birliği içerisinde her alanda Ruslaştırma politikası uygulamıştır. Bu yıllar arasında en önemlileri alfabe, dil, eğitim ve kimlik olmak üzere her alanda Sovyet insanı yaratmak amacına yönelik politikalar uygulanmıştır. Bunların başında da "dil planlaması" gelmektedir (Gökdağ, 2002, s. 93-107; Aliyeva, 2005, s. 34-109).

“Dil değişkelerinin işlev ve yapısını etkileyecek yazım, standartlaştırma, çağdaşlaştırma programları veya çok dilli toplumlarda belli bir dile işlevlerin yüklenmesi gibi bütün bilinçli gayretler" olarak tanımlanan dil planlaması, siyasî bir uygulamadır ve bu nedenle dil siyaseti olarak da tanımlanır. Buna göre dil siyaseti de "dil plânlamasının hükûmetler tarafından uygulanmasıdır." Diğer bir ifadeyle "hâkim gruplar tarafından dil kullanımında egemenliği kurma mekanizmasıdır." (Tollefson, 1991, s. 16; Aliyeva, 2005, s. 19'dan).

SSCB döneminde Azerbaycan SSC'de ${ }^{40}$ izlenen dil planlama politikası, Merkezi Komite Kurultayı'nda alınan kararlar sonucunda, başta gazete, dergi olmak üzere, kitle iletişim araçları, okullar, Millî Eğitim Bakanlığı ve Bilimler Akademisinin Dilcilik Enstitüsü, Edebiyat Enstitüsü,

\footnotetext{
${ }^{40}$ Azerbaycan Sovyet Sosyalist Cumhuriyeti
} 
Tarih Enstitüsü aracıllğıyla uygulamaya konmuştur (Aliyeva, 2005, s. 215, 221, 363). Bu uygulamaların belki de en dikkat çekici tarafı, 1938-1939 yıllarında Stalin döneminde yoğunlaşan ve bilimsel, teknik alandaki gelişmeler ile ilişkilendirilen dildeki değişikliklerin dil plânlaması uygulayıcılarından olan dil bilimciler tarafından yapılmış olmasıdır¹ (Aliyeva, 2005, s. 289).

Rus olmayan halkların Rusya'ya "entegre" edilmesi adı altında Ruslaştırılma hedefine yönelik bu politikayı Çarlık Rusyası döneminde Rus Ortodoks misyoner ve aynı zamanda bir ilahiyat profesörü olan Nikolay İvanoviç İlminsky başlatmış ve yürütmüştür. İlminsky'ye göre, Rus olmayan halkların Ruslaştırılmasının tek yolu bu halklara Rus dilinin ve Hristiyanlığın (Ortodoks) öğretilmesidir (Uzman, 2005, s. 30-36). Bunun için öncelikle Rus (Kiril) alfabesini bütün Müslüman-Türk halklarının lehçelerinde uygulayarak hem Rus kültürünü ve Ortodoksluğu bu halklara öğretmeyi hem de ortak bir dil konuşan halkları yazılı iletişimleri zayıflatılarak birbirlerinden uzaklaştırmayı hedeflemiştir (Gökdağ, 2002, s. 93-107; Süleymanlı, 2006, s. 80-84). Böylece, Rusların Türkleri Rus okullarına gitmeye zorlaması ve onları Hristiyanlaştırmaya çalışması tepki çekip başarısızlığa uğrayınca SSCB yönetimi farklı bir yöntem uygulamaya girişmiş, Türkleri zorla Rus okullarına göndermek yerine kendi dillerini öğrenme, okulda ve kilisede kullanma hakkı verme yoluna gitmiştir (Akalın, 2013, s. 364-365). İşte bu süreçte, bir taraftan kimlikleri yeniden inşa edilmeye çalışılan Türklerin, konuşma dillerinin de ayrı ayrı Rus (Kiril) alfabeleri üretilerek yazıya geçirilmesiyle yeni diller (yazı dilleri) ortaya çıarılmaya çalışılmıştır.

Azerbaycan Türkçesinin "dil planlaması" kapsamında yazı diline dönüştürülme sürecinde yazıya geçirme, dilbilgisinin yazımı ve yeni bir söz varlığı ortaya çıkarma ile yazım konusu da üzerinde çok durulan, çalışılan bir konu olmuştur. Dönemin Türkiye Türkçesiyle de ortak olan birçok yazım özelliği, 1920'li yıllarda "yanlış ve ciddî bir imlâ hatası" olarak görülmüş ve bu örnekler ağız özelliklerinin yazı diline girmesi ile açılanmıştır. İşte bu örnekler günümüzde, “SSCB dil siyasetinin bir plânlaması olarak Türk halklarının ortak kullandığı kelimelerin diyalekt şekillerinin edebî dile sokulup yaygınlaştırılması yoluyla Türk halklarının edebî dillerinin birbirlerinden uzaklaştırılma" çalışması olarak açıklanmaktadır (Aliyeva, 2005, s. 271). Buradan da anlaşılmaktadır ki Türkiye Türkçesiyle ortak olan yazım, sözcük veya anlam ve ekler, yeni “oluşturulan” Azerbaycan Türkçesinden bilinçli olarak çıkarılmaya çalışılmıştır.

Genelde Sovyet coğrafyasında yaşayan bütün Türkler, özelde ise Azerbaycan Türkleri bu politikalardan çok etkilenmiş ve sonucunda resmî Türk kimliği ortadan kaldırılarak önceleri Türk adını taşıyan halk için Azerbaycanlı, Azeri; daha önce Türkçe adıyla adlandırılan dil için ise Azerbaycanca, Azerbaycan Dili gibi ifadeler kullanılmıştır (Karataş, 2018, s. 431-437). ${ }^{42}$

\footnotetext{
41 “Milliyetler politikası temelinde uygulanan dil plânlamasında, özellikle Rus olmayan toplumların millî kültür ve millî tarihlerine has birçok kelime, kavram sözlüklerden atılarak unutturulmaya çalışılmış, yerine sosyalist ideolojisine hizmet eden ifadeler alınmış ya da eskiden sözlük anlamı herkes tarafından aynı kavranan kelimeler bilinçlere anlamca değiştirilerek farklı aşılanmıştır." (Aliyeva, 2005, s. 77). Ayrıca aydınlar, Azerbaycan Türkçesine uygun olmadığı düşünülen sözcük, terim ve ekleri Azerbaycan Türkçesinin temizlenmesi gerekçesiyle dilden çıkararak kendilerine verilen talimatları uygulamışlardır. Bu uygulamalar sonucunda 1940'lı yıllardan sonra Azerbaycan Türkçesinde önceleri kullanılan Türk kökenli ortak sözcüklere rastlamak mümkün olmamıştır (Aliyeva, 2005, s. 290).

42 Azerbaycan Türklerinin konuştuğu dilin tarihi süreç içerisindeki adının değişmesine dair ayrıntılı bilgi için bk. Karataş, 2018, s. 431-440.
} 
Komünist Parti yönetiminin uyguladığı merkezî dil plânlaması politikasının sonucunda dil ve alfabedeki değişimin çok açık bir biçimde takip edilebildiği alan Azerbaycan basını olmuştur. Azerbaycan basınında bu dönemde onlarca dergi ve gazete bulunmaktadır. Sovyet iktidarı, Bolşevik ideolojisini kitlelere ulaştırmak için başta gazete ve dergi olmak üzere kitle iletişim araçlarını çok etkin bir biçimde kullanmıştır. Lenin döneminden itibaren açık bir biçimde görülen ideyaca milli, mazmunca sosialist ("şekilce, görünüşte millî, muhtevaca sosyalist kültür") yayın politikası sonucunda millî Azerbaycan basını; Bolşevik, partili bir "Sovyet basını" na dönüşmüştür. $\mathrm{Bu}$ dönemde yayımlanan en önemli gazete, 70 yıl boyunca yayın hayatına aralıksız devam eden Kommunist gazetesi olmuştur ${ }^{43}$ (Akpınar, 2001, s. 385-388; Aliyeva, 2005, s. 68, 71; Karataş, 2018, s. 858-859).

Kommunist gazetesinin ilk sayısı 29 Ağustos 1919'da Azerbaycan Bolşeviklerinin gizli matbaasında yayımlanmıştır. "Sovet Respublikası Müvəqqəti Hərbi-İnqilabi Komitəsinin ve Azərbaycan Kommunist (Bolşeviklər) Partiyası Mərkəzi Komitəsinin bir yayın organı" olduğu ilk sayfasında ilan edilen Kommunist gazetesi, resmî olarak yayın hayatına 30 Nisan 1920'de başlamış ve 27 Ağustos 1991'e kadar da yayımlanmaya devam etmiştir. Gazetenin ilk resmî redaktörlügüüü Oliheydər Qarayev yapmıştır. Gazete daha sonraki dönemde "Xalq qəzeti” adını alarak günümüze kadar yayın hayatına devam etmiştir (Məhərrəmov, Məhərrəmli, 2009, s. 11-13; Karataş, 2018, s. 860).

Bahsedilen bütün bu özellikleri nedeniyle, SSCB'de alfabe, dil ve kimlik üzerinden yürütülen asimilasyon "benzeştirme" politikalarının anlaşılabilmesi için 30 Nisan 1920'de resmî olarak yayın hayatına başlayan Kommunist gazetesi çok önemli bir kaynaktır (Karataş, 2018, s. 861-862).

Alfabe konusu da SSCB'de yaşayan Türk boyları için çok önemli bir konu olmuştur. Geçmişte yaşanan siyasi, sosyal ve ekonomik değişimler sonucunda Azerbaycan Türkçesi için de tarih boyunca farklı alfabeler kullanılmıştır. ${ }^{44} \mathrm{Bu}$ alfabe değişiklikleri Kommunist gazetesine de yansımıştır. İlk sayısı 29 Ağustos 1919'da Türkçe (Azerbaycan Türkçesi) olarak yayımlanan Kommunist gazetesi, Arap harfleriyle basılmaya başlamış ve Kiril harfli bazı Rusça ilanlar haricinde birkaç yıl sadece Arap harfli baskısına devam etmiştir. 1924 yılından itibaren tek bir sütunda Latin alfabesiyle yazılar yayımlanırken 1926 yılında Latin harfli metinler bir sayfaya çıkarılmıştır. 01.01.1929 tarihinden itibaren de gazete tamamıla Latin harfleriyle yayımlanmaya başlamıştır. Gazete 01.01.1940-27.08.1991 tarihleri arasında da Kiril harfleriyle yayımlanmıştır (Karataş, 2017, s. 2018).

Üç farklı alfabeyle çok uzun süre yayımlanmış olması nedeniyle Kommunist gazetesi, dil ve yazımın incelenebilmesi, Azerbaycan Türkçesindeki fonetik ve morfolojik unsurların takip edilebilmesi açısından büyük öneme sahiptir. Bu açıdan bakıldığında özellikle Oğuz Türkçesinde belirgin değişimleri görülen belirtme durumu çekiminin gazetenin farklı alfabelerle yayımlanmış sayılarındaki örnekleri, bu değişimin niteliğini açık bir biçimde göstermektedir.

\footnotetext{
${ }^{43}$ Sovyet Dönemi Azerbaycan basınında Kommunist gazetesi ve dili ile ilgili ayrıntılı bilgi için bk. Karataş, 2018, s. 857874.

${ }^{44} \mathrm{Bu}$ kullanılan farklı alfabeler dönemleriyle birlikte şöyledir: 13. yüzyıl-1922/1929: Arap alfabesi; 1922-1937: Latin alfabesi; 1937-1940: Latin alfabesi; 1940-1991: Kiril alfabesi; 1992-1995: Latin ve Kiril alfabeleri; 1995-2001: Latin ve Kiril alfabeleri; 1 Ağustos 2001 yılından itibaren Latin Alfabesi kullanılmaktadır (Karataş, 2018, s. 461).
} 


\section{KOMMUNIST GAZETESINNDE BELİRTME DURUMU ÇEKIMI}

\subsection{Yalın İsimlerin Çekimi}

Sovyet Dönemi Azerbaycan Türkçesi metni olan Kommunist gazetesinde isimlerin ekli belirtme durumu çekiminde dört farklı biçim bulunmaktadır:

a. Ünlüyle Biten İsim Tabanı $+\{+(y) X\}$

b. Ünlüyle Biten İsim Tabanı $+\{+n X\}$

c. Ünsüzle Biten İsim Tabanı $+\{+X\}$

ç. Ünsüzle Biten İsim Tabanı $+\{+n X\}$

Çekime giren ismin son sesine ve farklı ses olaylarına (ses türemesi/yardım ses) göre ortaya çıan bu farklı eklerin, Kommunist gazetesindeki Arap, Latin ve Kiril harfli metinlerdeki kullanım sıklıklarının da farklı olduğu görülmektedir.

\subsection{1. Ünlüyle Biten İsim Tabanı $+\{(y) X\}$}

\section{Arap Harfli Kommunist Gazetesi ${ }^{45}$}

Kommunist gazetesinden alınan Arap harfli metinlerde, sonu ünlüyle biten yalın isimlerin belirtme durumu çekiminde yardımcı ünsüz (bağlantı ünsüzü)/y/ ile birlikte $\{+X\}$ eki kullanılmış ve bunlar Türkçenin Arap harfli yazım geleneğine göre ye (⿶) harfi ile yazılmıştır.

İncelenen metinlerde görüldüğü kadarıyla, Sovyet Dönemi Azerbaycan Türkçesindeki bu tür belirtme durumu çekimi, Türkiye Türkçesindekiyle aynıdır. Diğer bir ifadeyle, 20. yüzyılın henüz başında Arap alfabesiyle yazılan Azerbaycan Türkçesi ile Türkiye Türkçesinde ünlüyle biten isim tabanlarının belirtme durumu çekiminde /y/ yardımcı ünsüz ile birlikte aynı ekler kullanılmış ve bunlar da aynı harfle (⿶) yazılmıştır:

\begin{tabular}{|c|c|c|}
\hline \multicolumn{3}{|c|}{ SOVYET DÖNEMİ AZERBAYCAN TÜRKÇESİ } \\
\hline \multicolumn{3}{|c|}{ Arap Alfabesi ${ }^{46}$} \\
\hline $0:-6$ & nahiyə $+y+i$ (muhafiza et-) & $1922 / 8 / 1 / N 170$ \\
\hline c:alen & masala $+y+i$ (qaldır-) & 1925/1/8/N6 \\
\hline الطالمال & ahali $+y+i$ (tasis et-) & 1922/8/1/N170 \\
\hline 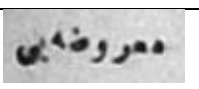 & $m a r u z \partial+y+i($ tasvib et-) & 1921/2/11/N9 \\
\hline •? & $m e y v \partial+y+i(y e-)$ & $1921 / 2 / 11 / \mathrm{N} 9$ \\
\hline
\end{tabular}

Sovyet Dönemi Azerbaycan Türkçesindeki bu çekim türünde dikkati çeken iki konu bulunmaktadır: Bunlardan birincisi /y/ yardımcı ünsüzü, ikinci ise belirtme durumu ekinin düzlük-yuvarlaklık uyumudur.

\footnotetext{
45 29.08.1919-01.01.1929

${ }^{46} \mathrm{Bu}$ çalışmada Kommunist gazetesinin Arap harfli metinlerinden alınan ve köken olarak alıntı (Arapça, Farsça) örnekler, çağdaş Azerbaycan Türkçesindeki biçimleriyle, Türkçe kökenli sözcükler ise yazımına uygun bir biçimde okunmuş ve yazılmıştır.
} 
Türkçede ünlüyle biten bir sözcügün ünlüden oluşan ya da ünlüyle başlayan bir ek alması durumunda, iki ünlünün yan yana bulunamaması nedeniyle burada bir /y/ ünsüzü türetilir. Bu sese Türk dilciliğinde genel olarak yardımcı ünsüz adı verilir. ${ }^{47}$ Türkçede temel yardımcı ünsüz /y/ olmakla birlikte, bir de sinırlı bir kullanım alanı bulunan ve ET'de zamirlerin yönelme durumu çekiminde ortaya çıkıp daha sonra iyelikli ve $\{+k i\}$ aitlik ekinin bulunduğu isimlere de bulaştığı için “zamir n'si” (pronominal n) adı verilen ${ }^{48}$ bir /n/ sesi de vardır"49 (Ergin, 1986, s. 145-146). Bu iki yardımcı ünsüzün Türkçenin kollarında farklı kullanım alanlarına sahip olduğu görülür. Buna göre /y/ ünsüzü bütün Türk lehçelerinde kullanılırken /n/ yardımcı ünsüzünün Doğu Türkçesinde Çağatay Türkçesinden itibaren özellikle de mensur eserlerde düşmeye başladığı, şiirde ise vezin gereği kullanıldığı belirtilmektedir (Eckmann, 1996, s. 142; Erdem Uçar, 2015, s. 27). Kıpçak grubu Türk lehçelerinde ise /n/ yardımcı ünsüzü /y/ ile birlikte kullanılmaya devam etmektedir (Öner, 1998, s. 21).

Azerbaycan dilciliğinde, genel olarak, ünlüyle biten isimlerin belirtme durumu çekiminde kullanılan $\{+n X\}$ ekindeki $/ \mathrm{n} /$ sesi bitişdirici ses, yani yardımcı ses olarak ${ }^{50}$ kabul edilmektedir ${ }^{51}$ (Mirzəzadə, 1962, s. 79; Hüseynzadə, 2007, s. 50; Kazımov, 2010, s. 77; Tanrıverdi, 2014, s. 202). Bu nedenle Azerbaycan Türkçesi tarihindeki belirtme durumu çekiminde görülen ek farklılıkları $(+(\mathrm{y}) \mathrm{X},+\mathrm{nX}), \quad / \mathrm{y} /$ ve /n/ yardımc seslerinin kullanım alanları ve yaygınlı̆̆ 1 üzerinden açıklanmaktadır. Buna göre belirtme durumu çekimindeki farklılık hakkında bilgi verilirken bir Oğuz grubu Türk lehçesi olan Azerbaycan Türkçesinin tarihinde, 18. yüzyıla kadar hem /y/'nin hem de /n/'nin bitişdirici ses olarak kullanıldığı, bu yüzyıldan sonra /n/ sesinin daha sık kullanılmaya başladığı ve 19. yüzyılın başından itibaren /y/ sesinin artık çok az örnekte göründüğ̈̆̈52 ifade edilmektedir (Mirzəzadə, 1962, s. 79). Ayrıca, belirtme durumu çekiminde /y/ sesinin yardımcı ses olarak kullanılmasının Azerbaycan yazı dilinde 1920-1940 yılları arasında, yani Sovyet Dönemi'nde de görüldüğü, ancak bu kullanımın yazı dilinde kaldığı, halkın konuşma diline yansımadığ da dile getirilmektedir (Ozizov, 1999, s. 171).

Mirzəzadə tarafından 20. yüzyılın başlarında Azerbaycan Türkçesinde genel olarak/y/ yardımcı sesinin çok az örnekte görüldüğünün belirtilmesine (1962, s. 79) rağmen Kommunist

\footnotetext{
47 Türklük biliminde yardımcı ses terimi için koruma ünsüzü (sesdeşi, konsonu, konsonantl), koruyucu ünsüz (sessiz), doldurma sesi, bağlama açını̆̆ı, bağlantı ünlüsü, ekleme ünlüsü, boşluk doldurucu, kaynaştırma harfi (sesi, ünsüzü) terimleri de kullanılmaktadır (Ercilasun, 2007, s. 347; Topaloğlu, 1989, s. 159).

48 "Zamir n'si" adı verilen sesle ve bu sesin ilişkili olduğu dilbilgisi yapıları ile ilgili önemli çalışmalar yapıllmıştır. Bu çalışmalar için bk. Bulak, Ulutaş, 2017, s. 453. Ayrıca bk. Kılıç, Ersöz 2020.

49 Türkçede yardımcı ses konusunda ayrıntılı bilgi ve tartışmalar için bk. Ercilasun, 2007, s. 347-352; Tekin, 2013, s. 487490. Ayrıca zamir n'si adı verilen sesin işlevleri ve ortaya çıkışı ile ilgili bk. Bulak, Ulutaş, 2017.

${ }^{50}$ Ozizov, belirtme durumu çekimindeki bu yapıları -yı, -yi, -yu, -yü ve -nı, -ni, -nu, -nü biçiminde ve şəkilçi ("ek") olarak göstermiştir. /y/ ve /n/ seslerini ise sadece element olarak ifade etmiştir (1999, s. 171-173).

51 Türkiye' deki Türklük Bilimi çalışmalarında ise Eski Türkçede işaret zamirlerinin çekiminde görülmeye başlayan $\{+n X\}$ ekindeki /n/ sesi bir yardımcı ses olarak değil, ekin yapısında bulunan bir ses ("morfolojik kalıntı") olarak kabul edilmektedir. Bu çalışmada da bu kabulden hareketle ek $\{+n X\}$ biçiminde gösterilmiştir. Ayrıntılı bilgi için bk. Kılıç, Ersöz 2020: 594-595.

52 Çağdaş Azerbaycan Türkçesi yazı dilinde /n/ sesinin ölçünlüleşmiş olmasına rağmen /y/ yardımcı sesinin Azerbaycan Türkçesinin batı grubu ağılarında korunarak kullanıldığı bilgisi verilmektedir (Mirzəzadə, 1962, s. 79-80; Әzizov, 1999, s. 172 ).
} 
gazetesinden alınan Arap harfli metinlerde ${ }^{53}$, sonu ünlüyle biten isimlerin belirtme durumu çekiminde yardımcı ünsüz /y/ sesinin çok sık kullanılmış olması son derece dikkat çekici bir durumdur.

Arap harfli Kommunist gazetesinden alınan metinlerdeki belirtme durumu çekimiyle ilgili üzerinde durulması gereken bir diğer konu da düzlük-yuvarlaklık uyumudur.

Belirtme durumu çekiminde Eski Türkçeden beri kullanılan $\{+X\}$ ekinin Arap harfli Türkçe metinlerde her zaman \{ $\}$ \}arfi ile yazılmış olması bu ekin uyuma girip girmediğinin anlaşılmasını zorlaştırmaktadır. Bu sorunun çözümünde aynı dönemlere ait yabancılar tarafından yapılmış Türkçenin Latin harfli dil bilgisi çalışmaları çok önemli bilgiler verebilmektedir. Bu çalışmalarla karşılaştırmalı olarak yapılmış bir incelemede, Osmanlı Türkçesinde belirtme durumu ekinin dudak uyumuna en son giren eklerden biri olduğu ve 19. yüzyılda uyuma girdiğinin belirlendiği ifade edilmiştir (Kartallığlu, 2011, s. 161-168). Bu bilgiden hareketle belirtme durumu ekinin aynı yüzyıllarda Azerbaycan Türkçesinde de uyuma girmiş olabileceğini söylemek mümkündür.54 Bunun ispatı da yine aynı gazetenin Arap harfleriyle birlikte yapılan Latin harfli yayınlarındaki örneklerdir.

Aşağ1da ekran görüntüsü verilen metindeki (1928-12-28-N302) “...olduğunu” sözünde bulunan belirtme durumu ekinin düzlük-yuvarlaklık uyumuna girdiği ve ekin, dönemin Latin alfabesinde /u/ sesinin karşılı̆̆ı olan (y) harfiyle yazıldığı görülmektedir:

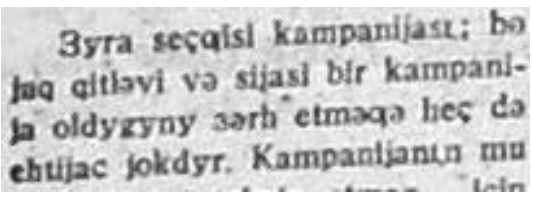

\section{Latin Harfli Kommunist Gazetesi ${ }^{55}$}

Kommunist gazetesinin Latin harfli metinlerinde ünlüyle biten isimlerin belirtme durumunun $\{+X\}$ eki ile çekimlendiği de görülmektedir. Ancak bu çekim biçiminin sıklığı, Arap harfli metinlere göre daha azdır. Bu örneklerde de Türkiye Türkçesinde olduğu gibi yardımcı ünsüz olarak/y/ sesi kullanılmıştır. Bu ses, Latin harfli metinlerde "j" harfi ile yazılmıştır:

\footnotetext{
53 İncelemede örneklem olarak Kommunist gazetesi kullanıldığı için dönemin diğer gazete ve yayınlarından (dergi, kitap) söz edilmemiş, onlardan örnek verilmemiştir. Ancak burada belirtilmelidir ki Kommunist gazetesinde görülen özellikler dönemin diğer yayınlarında da büyük ölçüde yer almaktadır.

54 Azerbaycan Türkçesinde yuvarlaklaşma (dodaqlanma / labiallaşma) ve düzleşme ("delabiallaşma”) ses olaylarını açılamaya çalışan Ozizov'a göre, söz sonunda görülen düzleşme ( $u>i>1, \ddot{u}>1)$ konusunda belirtme durumu çekimini de örneklerin arasında vermiş ve bunların tarihi metinlerde (ى) harfiyle yazıldı̆̆ını, metinlerin transkripsiyonunun yapılması sırasında bu harflerin art ünlüden oluşan sözlerde /1/, ön ünlüden oluşan sözlerde /i/ olarak okunduğunu dile getirmiştir. Yazar, Azerbaycan Türkçesinin Tebriz ve Şirvan ağızlarında da görülen bu düzleşme örneğinde /1/ seslerinin de /i/'ye yakın bir ses olduğunu, bu nedenle de M. Ergin tarafından yayımlanan Haydar Baba'ya Selam şiirinde yurdı, bozı, uzunı, guzunı biçiminde yazılan örnekleri, S. Çağatay'ın yurdi, bozi, uzuni, guzuni olarak yazdığını dile getirmiş ve Hacıyev'ın Azerbaycan yazı dilinde 16. yüzyıla kadar Tebriz ağzıyla birlikte Şirvan ağzının da etkili olduğunu, Şirvan ağzının da çağdaş Bakü ağzının temeli olduğunu, dolayısıyla 20. yüzyılın başlarında yazı dilindeki bazı özelliklerin (ör. düzleşme) güzey ve kuzeybatı grubu ağızlarındakilerle örtüştüğü yönündeki düşüncesiyle ifade etmiştir (1999, s. 163-165). Doğan da düzlük-yuvarlaklık uyumunun İran (Azerbaycan) Türk ağızlarında, belirtme durumu çekimlerinde ekin sadece düz-dar ünlülü biçimlerinin kullanılması nedeniyle bozulduğunu belirtmiş ve bu durumu örneklerle göstermiştir (2012, s. 924-925).

55 01.01.1929-01.01.1940
} 


\begin{tabular}{|c|c|c|}
\hline \multicolumn{3}{|c|}{ SOVYET DÖNEMİ AZERBAYCAN TÜRKÇESI } \\
\hline \multicolumn{3}{|c|}{ Latin Alfabesi } \\
\hline olifbajı, & alifba+y+ı (öyran-) & $1929 / 1 / 1 / \mathrm{N} 1$ \\
\hline syjy, & $s u+y+u$ (götür-) & $1929 / 1 / 1 / \mathrm{N} 1$ \\
\hline
\end{tabular}

\section{Kiril Harfli Kommunist Gazetesi ${ }^{56}$}

Kommunist gazetesinden alınan Kiril harfli metinlerde, sonu ünlüyle biten isimlerin belirtme durumu çekiminde yardımcı ünsüz (bağlantı ünsüzü) /y/ ile birlikte $\{+X\}$ ekinin kullanıldığı hiçbir örnek bulunmamaktadır. Bu dönem metinlerinde artık ünlüyle biten isim tabanlarının çekiminde ölçünlü olarak $\{+n X\}$ eki kullanılmaya başlamıştır.

Sonuç olarak, Kommunist gazetesinden alınan metinlere göre Sovyet Dönemi Azerbaycan Türkçesinde, ünlüyle biten isimlerin $\{+(\mathrm{y}) \mathrm{X}\}$ ekiyle yapılan belirtme durumu çekiminin Arap harfli metinlerde yaygın olarak kullanıldığı, Latin harfli metinlerde çok azaldığı, Kiril harfli metinlerde ise tamamen ortadan kalktığı ve çağdaş Azerbaycan Türkçesinde bu çekimin $\{+n X\}$ ekiyle yapıldığ görülmektedir (Hüseynzadə, 2007, s. 50). Bu çekimin günümüzde İran (Azerbaycan) Türk ağızlarında da dört değişkeli olarak kullanılmaya devam ettiği bilinmektedir (Doğan, 2012, s. 916).

Görüldüğü gibi Sovyet Dönemi Azerbaycan Türkçesinin kullanıldı̆̆ 1 Arap harfli Kommunist gazetesinde, sonu ünlüyle biten yalın isimlerin belirtme durumu çekimi Türkiye Türkçesi ile ortaktır. O dönemde her iki lehçedeki metinlerde, bu çekim türü $+\{(y) X\}$ ekiyle yapılmaktadır. Bu çekim biçimi Sovyet Dönemi Azerbaycan Türkçesinde 1940'lı yıllardan itibaren tamamen ortadan kalkmış, ancak Türkiye Türkçesinde ölçünlü olarak kullanılmaya devam etmiştir:

\begin{tabular}{|c|c|c|c|c|}
\hline \multicolumn{3}{|c|}{$\begin{array}{l}\text { SOVYET DÖNEMİ AZERBAYCAN TÜRKÇESI } \\
\qquad \ddot{u n l} \ddot{u}+\{(y) X\}\end{array}$} & $\begin{array}{l}\text { AZERBAYCAN } \\
\text { TÜRKÇESİ }\end{array}$ & $\begin{array}{l}\text { TÜRKİYE } \\
\text { TÜRKÇESİ }\end{array}$ \\
\hline Arap Alfabesi & Latin Alfabesi & Kiril Alfabesi & 21. yy. & 20-21.yу. \\
\hline $\begin{array}{l}\text { masala }+y+i \\
\text { maruza+y+i }\end{array}$ & $\begin{array}{l}a l i f b a+y+l \\
s u+y+u\end{array}$ & YOK & YOK & $\begin{array}{c}\text { arl+y+l } \\
\text { meyve+y+i } \\
\text { yolcu+y+u } \\
\ddot{u} t \ddot{u}+y+\ddot{u}\end{array}$ \\
\hline YAYGIN & $\mathrm{AZ}$ & & & ÖLÇÜNLÜ \\
\hline
\end{tabular}

\subsection{2. Ünlüyle Biten İsim Tabanı $+\{+n X\}$}

Arap Harfli Kommunist Gazetesi

Kommunist gazetesinden alınan Arap harfli metinlerde, belirtme durumu çekiminde ünlüyle biten isimlerden sonra gelen $\{+n X\}$ eki de kullanılmıştır ve bunlar \{ن\} harfleriyle yazılmıştır.

İncelenen metinlerde görüldüğü kadarıyla Sovyet Dönemi Azerbaycan Türkçesindeki bu tür belirtme durumu çekimi çok az sayıda örnekte kullanılmıştır: 


\begin{tabular}{|c|c|c|}
\hline \multicolumn{3}{|c|}{ SOVYET DÖNEMİ AZERBAYCAN TÜRKÇESİ } \\
\hline \multicolumn{3}{|c|}{ Arap Alfabesi 1919-1929 } \\
\hline باكونى & Bakl+nl (hesab it-) $)^{57}$ & 1921/2/14/N11 \\
\hline ithom & masala+ni (qoy-) & 1921/2/14/N11 \\
\hline
\end{tabular}

Eski Türkçede işaret zamirlerinin belirtme durumu çekiminde kullanılan ${ }^{58}\{+\mathrm{nI}\}$ ekinin bir taraftan tüm lehçelerde işaret zamirlerindeki kullanımı günümüze kadar devam ederken diğer taraftan da Karluk ve Kıpçak grubu Türk lehçelerinde isimlere de gelerek genel belirtme durumu eki olarak kullanıldığı bilinmektedir (Ergin, 1981, s. 136).

Köktürkçede genellikle işaret ve şahıs zamirlerinin çekiminde, Eski Uygur Türkçesinde ise ünlü ve ünsüzle biten isimlerde de görülen bu çekim biçiminin Oğuzcada da görüldüğü ve Eski Anadolu Türkçesinde az sayıda örnekte isimlere de geldiği belirtilmektedir (Gülsevin, 2007, s. 33). Eski Anadolu Türkçesinin ilk dönemine (Selçuklu) ait "karışık dilli/lehçeli”, yani farklı ağız özelliklerinin (kuzey ile batı ya da doğu ile batı) birlikte kullanıldığı eserlerde Doğu ve Kuzey Türkçesi özelliği olan $\{+n I\}$ belirtme durumu ekinin isimlerde de kullanıldığ görülmektedir (Koç, 2020, s. 66).

Oğuz grubu Türk lehçelerinde genel olarak sadece işaret zamirlerinde kullanılan $(b u+n \iota>$ bunu, şu+nı > şunu) bu ek, Azerbaycan Türkçesi tarihinde ünlüyle biten yalın isimlerin belirtme durumu çekiminde de kullanılmıştır.

Yukarıda da ifade edildiği gibi (3.1.1.) Azerbaycan dilciliğinde, Türkiye'deki ilgili çalışmalardan ${ }^{59}$ farklı olarak ünlüyle biten isimlerin belirtme durumu çekiminde kullanılan $\{+n X\}$ ekindeki /n/ sesi bitişdirici ses, yani yardımo ses olarak kabul edilmektedir. Belirtme durumu çekiminde $\{+n X\}$ ekinin kullanımının Azerbaycan Türkçesi /n/ sesinin yardımcı ses olarak kullanımıyla ilgili olduğu, 18. yüzyıla kadar hem /n/'nin /y/ ile birlikte bitişdirici ses olarak kullanıldığı, bu yüzyıldan sonra /n/ sesinin daha sık kullanılmaya başladığı ve 19. yüzyılın başından itibaren /y/ sesinin artık çok az örnekte göründüğü belirtilmiştir (Mirzəzadə, 1962, s. 79). $\mathrm{Bu}$ gelişme sonucunda Azerbaycan Türkçesinde ünlüyle biten isimlerin belirtme durumu çekiminde kullanılan $\{+n X\}$ eki ölçünlüleşmiştir.

Kommunist gazetesinden alınan Sovyet Dönemi Azerbaycan Türkçesinin Arap harfli metinlerinde dikkat çekici olan durum, ünlüyle biten isimlerden sonra kullanılan $\{+n X\}$ belirtme durumu ekinin çok az sayıda örnekte görülmüş olmasıdır.

\footnotetext{
57 Türkiye'de Bakü, Azerbaycan'da ise Bakı biçiminde söylenip yazılan bu sözcük, Arap harfli metinlerde, muhtemelen Rusça söyleniş (Баку /Baku/) etkisiyle be, elif, kef ve vav ile (باكو) yazılmaktadır. Vav harfi sözcügün yuvarlak ünlülü olduğunu göstermektedir. Ancak Latin ve Kiril harfli metinlerde sözcük dar ünlülü (/1/) yazılmıştır: Bakbda (1939/3/3/N50, s. 1), Бакbl (1940/8/29/N50, s. 1).

${ }^{58} \mathrm{Bu}$ eklerin, Eski Uygur Türkçesinde işaret ve şahıs zamirlerinin dişında isimlerin de belirtme durumu çekiminde kullanıldı̆̆ belirtilmektedir: buz+nı, suv+nı, yanturdaçı+nı vb. Ercilasun 2004: 281; Gabain 2007: 64, Doğan, 2012 , s. 9164. dipnot.

${ }^{59} \mathrm{Bu}$ sesin kökeni ile ilgili on bir farklı görüş olduğu belirtilmektedir (K1lıç ile Ersöz 2020: 579). Örneğin Kılıç ile Ersöz'e göre, "İşaret zamirleri ile hâl ekleri arasına giren /n/, zamir /n/'si olarak bilinen, bu makalede teklik kategorisi olarak değerlendirilen ve işaret zamirlerinin üzerinde donan /n/'dir." (2020: 588).
} 


\section{Latin Harfli Kommunist Gazetesi:}

Kommunist gazetesinden alınan Latin harfli metinlerde, belirtme durumu çekiminde ünlüyle biten isimlerden sonra gelen $\{+n X\}$ eki yaygın olarak kullanılmıştır:

\begin{tabular}{|c|c|c|}
\hline \multicolumn{3}{|c|}{ SOVYET DÖNEMI AZERBAYCAN TÜRKÇESI } \\
\hline \multicolumn{3}{|c|}{ Latin Alfabesi 1929-1940 } \\
\hline makaləni & meqala+ni (al-) & $1929 / 1 / 1 / \mathrm{N} 1$ \\
\hline ahalini & ahali+ni (uzaqlaşdır-) & $1929 / 1 / 1 / \mathrm{N} 1$ \\
\hline alifbanı, & alifba+nı (ortadan çıxar-) & $1929 / 1 / 1 / \mathrm{N} 1$ \\
\hline quj̣unu. & quyu+nu (al-) & $1939 / 3 / 3 / 50$ \\
\hline
\end{tabular}

İncelenen metinlerde, Sovyet Dönemi Azerbaycan Türkçesindeki bu tür belirtme durumu çekiminin kullanım sıklığının Arap harfli metinlere göre arttığı görülmektedir. Kommunist gazetesinin Arap harfli metinlerinde az sayıda örneği görülen bu çekim biçimi Azerbaycan Türkçesinde daha sonraki süreçte yaygınlaşmış ve ölçünlüleşmiştir.

Burada Sovyet Dönemi Azerbaycan Türkçesinin Arap Harfli metinlerinde Türkiye Türkçesiyle ortak olarak kullanılan ve $\{+(y) X\}$ ekiyle yapılan belirtme durumu çekiminin, Latin alfabesine geçildikten sonra farklılaşması ve ünlüyle biten isimlerden sonra gelen $\{+n X\}$ ekinin kullanılmaya başlamış olması dikkat çekicidir.

\section{Kiril Harfli Kommunist Gazetesi}

Kommunist gazetesinin Kiril harfli metinlerinde ünlüyle biten isimlerden sonra $\{+n X\}$ belirtme durumu eki yaygın olarak kullanılmaya başlamıştır. Bu durum, kullanım sıklığı Arap harfli metinlerden sonra artmaya başlayan $\{+n X\}$ ekinin Azerbaycan Türkçesinde Kiril harfli metinlerden itibaren ölçünlüleştiğini göstermektedir:

\begin{tabular}{|c|c|c|}
\hline \multicolumn{3}{|c|}{ SOVYET DÖNEMİ AZERBAYCAN TÜRKÇESİ } \\
\hline \multicolumn{3}{|c|}{$\begin{array}{l}\text { Kiril Alfabesi } \\
\end{array}$} \\
\hline МәсәләнН, & masala+ni (ifada et-) & $1940 / 1 / 3 / \mathrm{N} 2$ \\
\hline мүбаргзани & mübariza+ni (yüksalt-) & $1940 / 1 / 3 / \mathrm{N} 2$ \\
\hline Вәзифани & vazifa+ni (hall et-) & $1940 / 1 / 3 / \mathrm{N} 2$ \\
\hline
\end{tabular}

Sonuç olarak, Kommunist gazetesinden alınan metinlere göre Sovyet Dönemi Azerbaycan Türkçesinde, ünlüyle biten isimlerin $\{+n X\}$ ekiyle yapılan belirtme durumu çekiminin Arap harfli metinlerde çok az sayıda örnekte kullanıldığı, Latin harfli metinlerde arttığı, Kiril harfli metinlerde ise çok yaygınlaştığı ve çağdaş Azerbaycan Türkçesinde de bu biçimiyle ölçünlüleştiği görülmektedir (Hüseynzadə, 2007, s. 50-51). Bu çekim biçiminin İran (Azerbaycan) Türk ağızlarında da sadece ünlü ile biten isimlerden sonra dört değişkeyle kullanıldı̆̆ belirtilmektedir 
(Doğan, 2012, s. 916). Türkiye Türkçesinde ise bu çekim sadece zamirlerde kullanılmış, isimlerde hiçbir zaman kullanılmamıştır.

Bu bilgilere göre, Sovyet Dönemi Azerbaycan Türkçesindeki bu tür belirtme durumu çekiminin Azerbaycan Türkçesinde zaman içerisinde ölçünlüleşerek Türkiye Türkçesinden farklılaştığı anlaşılmaktadır:

\begin{tabular}{|c|c|c|c|c|}
\hline \multicolumn{3}{|c|}{$\begin{array}{l}\text { SOVYET DÖNEMİ AZERBAYCAN TÜRKÇESI } \\
\qquad \ddot{u} n l \ddot{u}+\{+(n) X\}\end{array}$} & $\begin{array}{l}\text { AZERBAYCAN } \\
\text { TÜRKÇESİ }\end{array}$ & $\begin{array}{l}\text { TÜRKIIYE } \\
\text { TÜRKÇESI }\end{array}$ \\
\hline Arap Alfabesi & Latin Alfabesi & Kiril Alfabesi & 21. yy. & 20-21.yy. \\
\hline $\begin{array}{l}\text { Bakü+nü } \\
m a s \partial l \partial+n i\end{array}$ & $\begin{array}{l}\text { maqala+ni } \\
\text { alifba+nı } \\
q u y u+n u\end{array}$ & $v a z i f \partial+n i$ & $\begin{array}{l}\text { tayyara+ni } \\
\text { dayı+nı } \\
\text { kino+nu } \\
\text { körpü+nü }\end{array}$ & YOK \\
\hline ÇOK AZ & YAYGIN & ÖLÇÜNLÜ & ÖLÇÜNLÜ & \\
\hline
\end{tabular}

\subsection{3. Ünsüzle Biten İsim Tabanı $+\{+X\}$}

\section{Arap Harfli Kommunist Gazetesi}

Arap harfli Kommunist gazetesinden alınan metinlerde, sonu ünsüzle biten isimlerin belirtme durumu çekiminde $\{+X\}$ eki kullanılmış ve bunlar Türkçenin Arap harfli yazım geleneğine göre \{⿶\} harfi ile yazılmıştır.

Sovyet Dönemi Azerbaycan Türkçesinin Arap harfli metinlerinde görülen diğer belirtme durumu çekimlerinde olduğu gibi bu çekim biçiminin de düzlük-yuvarlaklık uyumuna girmiş olduğu, aynı gazete ve sayıda yer alan Latin harfli örneklerden anlaşılmaktadır:

\begin{tabular}{|c|c|c|}
\hline \multicolumn{3}{|c|}{ SOVYET DÖNEMİ AZERBAYCAN TÜRKÇESİ } \\
\hline \multicolumn{3}{|c|}{ Arap Alfabesi } \\
\hline (b) & tabur $+u($ salamla-) & 1922/8/1/N170 \\
\hline ilogtho & molumat $+\iota$ (tasvir eyla-) & 1922/8/1/N170 \\
\hline ollatiol & istintak $+\imath$ (sübut et-) & 1922/8/1/N170 \\
\hline
\end{tabular}

\section{Latin Harfli Kommunist Gazetesi}

Kommunist gazetesinden alınan Latin harfli metinlerde, sonu ünsüzle biten isimlerin belirtme durumu çekiminde $\{+X\}$ eki ölçünlü olarak kullanılmıştır: 


\begin{tabular}{|c|c|c|}
\hline \multicolumn{3}{|c|}{ SOVYET DÖNEMİ AZERBAYCAN TÜRKÇESİ } \\
\hline \multicolumn{3}{|c|}{$\begin{array}{l}\text { Latin Alfabesi } \\
\end{array}$} \\
\hline mวdว̇nijjəti & madaniyyat $+i$ (yüksalt-) & 1929/1/1/N1 \\
\hline toprakt. & torpaq+l (sat-) & 1929/1/1/N1 \\
\hline hucymy & hücum+u (güçlandir-) & 1930/1/15/N12 \\
\hline rajont & rayon $+u$ (nazarda tut-) & $1939 / 3 / 3 / \mathrm{N} 50$ \\
\hline
\end{tabular}

\section{Kiril Harfli Kommunist Gazetesi}

Kommunist gazetesinden alınan Kiril harfli metinlerde, Sovyet Dönemi Azerbaycan Türkçesinde, ünsüzle biten isimlerin $\{+X\}$ ekiyle yapılan belirtme durumu çekiminin Arap ve Latin'den sonra Kiril harfli metinlerde de ölçünlü olduğu görülmektedir:

\begin{tabular}{|c|c|c|}
\hline \multicolumn{3}{|c|}{ SOVYET DÖNEMİ AZERBAYCAN TÜRKÇESİ } \\
\hline \multicolumn{3}{|c|}{ Kiril Alfabesi } \\
\hline nхане & plan $+\imath$ (yerina yetir-) & 1940/1/4/N3 \\
\hline ВэтәНН & veten $+i$ (müdafiz et-) & 1940/1/1/N1 \\
\hline
\end{tabular}

Sonuç olarak, Kommunist gazetesinden alınan metinlere göre Sovyet Dönemi Azerbaycan Türkçesinde, ünlüyle biten isimlerin $\{+X\}$ ekiyle yapılan belirtme durumu çekiminin Arap, Latin ve Kiril harfli metinlerde ölçünlü olarak kullanıldığı çağdaş Azerbaycan Türkçesinde de bu kullanımın devam ettiği görülmektedir (Hüseynzadə, 2007, s. 50-51). Türkiye Türkçesinde de bu çekim aynı eklerle yapılagelmiştir ve bu çekim biçiminin Azerbaycan Türkçesi ile Türkiye Türkçesi arasındaki temel ortaklıklardan biri olduğu anlaşılmaktadır:

\begin{tabular}{|c|c|c|c|c|}
\hline \multicolumn{3}{|c|}{$\begin{array}{l}\text { SOVYET DÖNEMİ AZERBAYCAN TÜRKÇESI } \\
\qquad \ddot{u} n s \ddot{u} z+\{+X\}\end{array}$} & $\begin{array}{l}\text { AZERBAYCAN } \\
\text { TÜRKÇESİ }\end{array}$ & $\begin{array}{l}\text { TÜRKIYYE } \\
\text { TÜRKÇESİ }\end{array}$ \\
\hline Arap Alfabesi & Latin Alfabesi & Kiril Alfabesi & 21. yy. & 20-21.yy. \\
\hline $\begin{array}{l}\text { tabur }+u \\
\text { molumat+ı } \\
\text { istintak+ı }\end{array}$ & $\begin{array}{l}\text { madaniyyat }+i \text { torpaq }+l \\
\text { rayon }+u\end{array}$ & $\begin{array}{l}\text { plan+i } \\
\text { vatan+i }\end{array}$ & 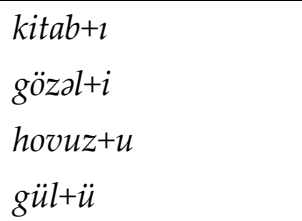 & 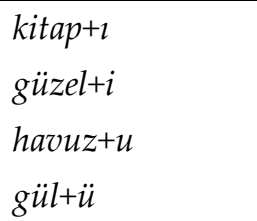 \\
\hline \multicolumn{5}{|c|}{ ÖLÇÜNLÜ } \\
\hline
\end{tabular}

\subsection{4. Ünsüzle Biten İsim Tabanı $+\{+n X\}$}

\section{Arap Harfli Kommunist Gazetesi:}

Kommunist gazetesinden alınan Arap harfli metinlerde, sonu ünsüzle biten yalın isimlerin belirtme durumu çekiminde $\{+n X\}$ ekinin sadece bir örnekte kullanıldığı görülmüştür. Bu örnekte ek $\{$ \} harfleriyle yazılmıştır: 


\begin{tabular}{|c|c|c|}
\hline \multicolumn{3}{|c|}{ SOVYET DÖNEMİ AZERBAYCAN TÜRKÇESİ } \\
\hline \multicolumn{3}{|c|}{ Arap Alfabesi 1919-1929 } \\
\hline$j\left(\mathcal{S}_{i}\right)$. & anket+ni (göndər-) & $1924 / 11 / 4 /$ N246 \\
\hline
\end{tabular}

Kommunist gazetesinden alınan örnekte de görüldüğü gibi, belirtme durumu çekiminde ünsüzle biten isimlerden sonra da $\{+$ ni $\}$ eki kullanılmıştır. Ancak buradaki $\{+$ ni $\}$ ekinin parantez içindeki anket sözüne doğrudan eklenmemiş olması, parantezden sonra konması dikkat çekicidir. Gazetede başka bir örneğinin bulunamaması ve burada da özel bir biçimde kullanılması, bu çekimin yok denecek kadar az olduğunun bir göstergesidir.

Azerbaycan Türkçesi tarihinde 15. yüzyıldan itibaren (ör. Hatayî ve Kişverî̀de) aynı zamanda zamirlerin belirtme durumu çekiminde de kullanılan $\{+n X\}$ eki, sadece ünlüyle biten isimlerin değil, ünsüzle biten isimlerin de belirtme durumu çekimlerinde, çok az da olsa, kullanılmaya başlamıştır. Mirzəzadə’ye göre, 15. yüzyıldan itibaren kullanılan ve yazı dili ile günümüze kadar korunarak aktarılan bu çekimin Azerbaycan Türkçesi ağızlarında hiçbir örneği bulunmadığı için bu özellik geniş halk kitlelerinin kullandığı Azerbaycan Türkçesi yazı diline yerleşememiştir. Dolayısıyla bu tür belirtme çekiminin diğer Türk lehçelerinden gelen bir etki olduğu söylenebilir. Bu etki de 15-17. yüzyıllarda Türkistan'da (Orta Asya) yaşayan diğer Türk şairleri ile Azerbaycanlı şairlerin edebî etkileşimi sonucunda gerçekleşmiş olmalıdır. Çünkü bu çekim biçimi şiir dilinde daha çok görülmektedir (Mirzəzadə, 1962, s. 82).

$\mathrm{Bu}$ bilgilere göre, $\{+n X\}$ ekinin doğu ve kuzey grubu Türk lehçelerinden Azerbaycan Türkçesine geçtiğini, Azerbaycan Türkçesinde önce ünlüyle biten isimlerin belirtme durumu çekimlerinde kullanıldığını, ardından çok nadir olarak ünsüzle biten isimlerde de kullanılmaya başladı̆̆ını ve bunun da bir "bulaşma" sonucunda gerçekleşmiş olabileceğini söylemek mümkündür.

\section{Latin Harfli Kommunist Gazetesi}

Kommunist gazetesinden alınan Latin harfli metinlerde, sonu ünsüzle biten yalın isimlerin belirtme durumu çekiminde de $\{+n X\}$ ekinin kullanıldığı herhangi bir örnek bulunamamıştır.

\section{Kiril Harfli Kommunist Gazetesi:}

Kiril harfli Kommunist gazetesinden alınan metinlerde de sonu ünsüzle biten yalın isimlerin belirtme durumu çekiminde de $\{+n X\}$ ekinin kullanıldığı herhangi bir örnek bulunamamıştır.

Kommunist gazetesinden alınan metinlere göre Sovyet Dönemi Azerbaycan Türkçesinde, ünsüzle biten isimlerin $\{+n X\}$ ekiyle yapılan belirtme durumu çekiminin Arap, Latin ve Kiril harfli metinlerde hemen hemen hiç kullanılmadı $\breve{g}_{1}$ ve bu çekim biçiminin çağdaş Azerbaycan Türkçesinde tamamen ortadan kalktığı, bunun yerine $\{+X\}$ ekinin kullanıldı̆̆ı görülmektedir (Hüseynzadə, 2007, s. 50-51). Türkiye Türkçesinde ise bu çekim hiçbir zaman kullanılmamıştır.

Azerbaycan dilciliğinde, $+n I$ ekindeki sesin bitişdirici ses, yani yardımcı ses olarak kabul edildiği ifade edilmişti. Çağdaş Azerbaycan Türkçesinde ekin ünlü ile biten isimlere gelmiş olması 
/n/ sesinin yardımcı ses olarak yorumlanmasına neden olmuştur. Ancak bu ekin tarihî Azerbaycan Türkçesi metinlerinde ünsüzle biten isimlere de gelmiş olması buradaki sesin yardımcı ünsüz olamayacağını göstermektedir. Çünkü yardımcı ünsüz iki ünlünün bir araya gelmesi durumunda "fonetik bir imkânsızlığı gidermek için dilin bulduğu bir fonetik çözüm" olarak kullanılır (Ercilasun, 2000, s. 352). Ancak ünsüzle biten bir ismin doğrudan +I belirtme durumu eki almak yerine $+n I$ ekiyle çekime girmesi Türkçenin ses özellikleri açısından açıklanabilecek bir durum değildir. Zamir n'si adı verilen sesin kullanım alanları göz önüne alındığında iki ünlünün bir araya gelmesinden kaynaklanan bir ünlü çatışması olmadığı, bu nedenle de yardımcı sese ihtiyaç duyulmadığı görülmektedir (Bulak, Ulutaş, 2017, s. 457). Bu nedenle bu ekteki /n/ sesi, bir yardımcı ses değil şahıs zamirlerinin eskicil bir teklik kategorisinden gerçekleşen "morfolojik bir kalıntı"dır (Kılıç, Ersöz 2020: 579-588).

Ayrıca, Azerbaycan Türkçesi tarihinde 15. yüzyıldan itibaren hem işaret zamirlerinin hem de isimlerin belirtme durumu çekiminde de kullanılan $\{+n X\}$ ekinin Doğu ve Kuzey Türkçesi etkisiyle açıklanmış olması burada söz konusu olan ekin, Eski Türkçeden günümüze kadar çeşitli kullanım alanlarına sahip olan $+n I$ olduğunu, buradaki $/ n /$ sesinin de ekin bünyesinde bulunan bir ses olduğunu göstermektedir.

$\mathrm{Bu}$ bilgilere göre, $\{+n X\}$ ekinin ünlüyle biten isimlerden sonra Arap, Latin ve Kiril harfli Sovyet Dönemi Azerbaycan Türkçesi metinlerinde artan bir sıklıkta, ünsüzle biten isimlerden sonra ise çok az kullanıldığ görülmektedir. Ünsüzle Biten İsim Tabanı $+\{+n X\}$ çekiminin çağdaş Azerbaycan Türkçesinde hiç kullanılmaması, Sovyet Dönemi Azerbaycan Türkçesi metinlerindeki az sayıdaki örneğin de "bulaşma" ile ortaya çıtı̆̆ını ve bunların da yaygınlaşmadığını göstermektedir:

\begin{tabular}{|c|c|c|c|c|}
\hline \multicolumn{3}{|c|}{$\begin{array}{l}\text { SOVYET DÖNEMİ AZERBAYCAN TÜRKÇESI } \\
\qquad \ddot{u} n s \ddot{u} z+\{+n X\}\end{array}$} & $\begin{array}{l}\text { AZERBAYCAN } \\
\text { TÜRKÇESİ }\end{array}$ & $\begin{array}{l}\text { TÜRKİYE } \\
\text { TÜRKÇESİ }\end{array}$ \\
\hline Arap Alfabesi & Latin Alfabesi & Kiril Alfabesi & 21. yy. & 20-21.yy. \\
\hline anket $+n i$ & YOK & YOK & YOK & YOK \\
\hline Tek Örnek & & & & \\
\hline
\end{tabular}

\section{2. İyelik Ekli İsim Tabanı $+\{+(s) X(n) X\}$}

\section{Arap Harfli Kommunist Gazetesi}

Arap harfli Kommunist gazetesinde iyelik eki almış isimlerden sonra kullanılan belirtme durumu çekimi $\{+(s) X(n) X\}$ şeklindedir ${ }^{60}$ ve bu ekler Türkçenin Arap harfli yazım geleneğinde olduğu gibi \{ن\} biçiminde yazılmıştır.

\footnotetext{
60 Türklük bilimi çalışmalarında teklik üçüncü şahıs iyelik eki almış isimlerin belirtme durumu çekiminde kullanılan $\{+\mathrm{n}\}$ ekinin ve $\{+\mathrm{nX}\}$ ekindeki /n/ sesinin, genelde yardımcı ses olarak değil, iyelik ekinin bir parçası olarak kabul edilmesi (Tekin 2003: 131-138, Gülsevin, 2007; Kerimoğlu, 2007; Başdaş, 2008; Başdaş, 2009; Başdaş, 2014; Kılıç, Ersöz 2020) nedeniyle bu çalışmada ek $\{+(s) X(n) X\}$ biçiminde gösterilmiştir.
} 
İncelenen metinlerde görüldüğü kadarıyla Sovyet Dönemi Azerbaycan Türkçesindeki bu tür belirtme durumu çekiminde iyelik ekli isimlerden sonra $\{+(\mathrm{s}) \mathrm{X}(\mathrm{n}) \mathrm{X}\}$ eki ölçünlü olarak kullanılmıştır.

Sovyet Dönemi Azerbaycan Türkçesinin Arap harfli metinlerinde, bu çekim biçiminin de düzlük-yuvarlaklık uyumuna girmiş olduğu Latin harfli örneklerden anlaşılmaktadır:

\begin{tabular}{|c|c|c|}
\hline \multicolumn{3}{|c|}{ SOVYET DÖNEMİ AZERBAYCAN TÜRKÇESİ } \\
\hline \multicolumn{3}{|c|}{ Arap Alfabesi } \\
\hline $\cos ^{21} 3$ & (Türk) dil+i(n)+i(bil-) & $1925 / 1 / 8 / \mathrm{N} 6$ \\
\hline$\omega^{i}$ & $\operatorname{sinif}+i(n)+i(b u l-)$ & $1925 / 1 / 8 / \mathrm{N} 6$ \\
\hline فاتى & $\begin{array}{c}\text { tasarrufat }+\imath(n)+\imath \\
(\text { yüksalt-) }\end{array}$ & $1921 / 2 / 11 / \mathrm{N} 9$ \\
\hline & $c \partial b h \partial+\operatorname{si}(n)+i($ tamin et -$)$ & 1922/8/1/N170 \\
\hline & $n i t q+i(n)+i(b i t i r-)$ & 1922/8/1/N170 \\
\hline & $r o l+u(n)+u($ artır- $)$ & 1922/8/1/N170 \\
\hline
\end{tabular}

\section{Latin Harfli Kommunist Gazetesi}

Kommunist gazetesinden alınan örneklerde görüldüğü gibi, Sovyet Dönemi Azerbaycan Türkçesi belirtme durumu çekiminde iyelikli isimlerden sonra $\{+(\mathrm{s}) \mathrm{X}(\mathrm{n}) \mathrm{X}\}$ ekinin kullanımı ölçünlü olarak devam etmiştir:

\begin{tabular}{|c|c|c|}
\hline \multicolumn{3}{|c|}{ SOVYET DÖNEMİ AZERBAYCAN TÜRKÇESİ } \\
\hline \multicolumn{3}{|c|}{$\begin{array}{l}\text { Latin Alfabesi } \\
\end{array}$} \\
\hline lisanlartus & lisanlar $+\imath(n)+\imath($ poz- $)$ & 1929/1/1/N1 \\
\hline vazijjatini & $v \partial z i y y \partial t+i(n)+i($ yaxşılaşdır- $)$ & 1929/1/1/N1 \\
\hline masəlasini & $m a s a l a+s i(n)+i($ maydana at- $)$ & 1929/1/1/N1 \\
\hline topragınL & torpaq $+\imath(n)+\imath($ sat -$)$ & 1929/1/1/N1 \\
\hline qөquпu & $k o ̈ k+\ddot{u}(n)+\ddot{u}(k \partial s-)$ & 1939/3/3/N50 \\
\hline
\end{tabular}

\section{Kiril Harfli Kommunist Gazetesi}

Kommunist gazetesinin Kiril harfli metinlerinde de iyelik ekli isimlerin belirtme durumu çekiminde $\{+(\mathrm{s}) \mathrm{X}(\mathrm{n}) \mathrm{X}\}$ eki kullanılmıştır. Bu eklerin tüm Sovyet Dönemi Azerbaycan Türkçesinden itibaren ölçünlü olarak kullanıldığı görülmektedir: 


\begin{tabular}{|c|c|c|}
\hline \multicolumn{3}{|c|}{ SOVYET DÖNEMİ AZERBAYCAN TÜRKÇESİ } \\
\hline \multicolumn{3}{|c|}{$\begin{array}{l}\text { Kiril Alfabesi } \\
\end{array}$} \\
\hline Мvрачнәтини & müraciet $+i(n)+i$ (çap et-) & 1940/1/4/N3 \\
\hline талำ & $t \partial l \partial b+i(n)+i(\ddot{d} d \partial y \partial b i l-)$ & 1940/1/4/N3 \\
\hline Вәзนф์จсนнน & $v a z i f a+s i(n)+i$ (qarşıya qoy-) & $1940 / 1 / 3 / \mathrm{N} 2$ \\
\hline п.таныны & plan $+\imath(n)+\imath$ (yetir -$)$ & $1940 / 1 / 3 / \mathrm{N} 2$ \\
\hline рәһборнат: & $r a h b \partial r+i(n)+i($ tamin et -$)$ & 1940/1/1/N1 \\
\hline Yзуस् & $\ddot{u} z+\ddot{u}(n)+\ddot{u}($ qurtar-) & 1940/5/1/N100 \\
\hline
\end{tabular}

Kommunist gazetesinden alınan metinlere göre iyelik ekli isim tabanlarının Sovyet Dönemi Azerbaycan Türkçesinde Arap, Latin ve Kiril harfli tüm metinlerde $\{+(s) X(n) X\}$ ekiyle ölçünlü olarak kullanıldığı ve bu çekimin aynı şekilde çağdaş Azerbaycan Türkçesinde de ölçünlüleştiği görülmektedir (Hüseynzadə, 2007, s. 50-51). Türkiye Türkçesinde de bu çekim aynı şekilde kullanılmaktadır.

Eski Türkçede iyelik tabanlı isimlerin belirtme durumu çekiminde görülmeye başlayan $+n$ ekinin de Eski Anadolu Türkçesi döneminde yaygınca kullanıldı̆̆ı, Osmanlı Türkçesinde de varlığını sürdürdüğü, ancak Türkiye Türkçesinde ve Azerbaycan Türkçesinde kullanımdan düştüğü görülmektedir (Ergin, 1986, s. 232). Bununla birlikte, Eski Anadolu Türkçesindeki bu kullanımın İran (Azerbaycan) Türk ağızlarında korunduğu ve kullanıldığg belirtilmektedir (Doğan, 2012, s. 916).

$\mathrm{Bu}$ bilgilere göre, Sovyet Dönemi Azerbaycan Türkçesindeki bu tür belirtme durumu çekiminin Azerbaycan Türkçesi ile Türkiye Türkçesi arasındaki temel ortaklıklardan biri olduğu anlaşılmaktadır:

\begin{tabular}{|c|c|c|c|c|}
\hline \multicolumn{3}{|c|}{$\begin{array}{l}\text { SOVYET DÖNEMİ AZERBAYCAN TÜRKÇESİ } \\
\text { Iyelik }+\{+(n) X\}\end{array}$} & \multirow{2}{*}{$\begin{array}{c}\text { AZERBAYCAN } \\
\text { TÜRKÇESİ } \\
21 . y y .\end{array}$} & \multirow{2}{*}{$\begin{array}{c}\text { TÜRKİYE } \\
\text { TÜRKÇESİ }\end{array}$} \\
\hline Arap Alfabesi & Latin Alfabesi & Kiril Alfabesi & & \\
\hline $\begin{array}{l}\operatorname{sinif}+i(n)+i \\
(\text { Türk) dil+i(n)+i } \\
r o l+u(n)+u\end{array}$ & $\begin{array}{l}\text { lisanlar }+\imath(n)+\imath \\
m \partial s \partial l \partial+s i(n)+i \\
k \ddot{k}+\ddot{u}(n)+\ddot{u}\end{array}$ & 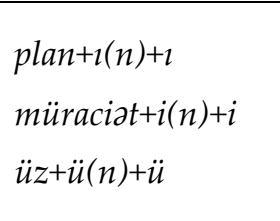 & $\begin{array}{l}\text { maşın+l(n)+l } \\
q a l b+i(n)+i \\
q o l+u(n)+u \\
g o ̈ z+\ddot{u}(n)+\ddot{u}\end{array}$ & $\begin{array}{c}k \imath z+\imath(n)+\imath \\
e v+i(n)+i \\
o y u n+u(n)+u \\
k o ̈ y+\ddot{u}(n)+\ddot{u}\end{array}$ \\
\hline \multicolumn{5}{|c|}{ ÖLÇÜNLÜ } \\
\hline
\end{tabular}

\subsection{Zamir $+\{+n X\}$}

\section{Arap Harfli Kommunist Gazetesi}

Arap harfli Kommunist gazetesi metinlerinde, zamirlerin belirtme durumu çekiminde $\{+n X\}$ ekleri kullanılmıştır. Bu ekler Türkçenin Arap harfli yazım geleneğinde olduğu gibi nun ve ye \{ن\} harfleriyle yazılmıştır. 
Sovyet Dönemi Azerbaycan Türkçesinin Arap harfli metinlerinde, bu çekim biçiminin de düzlük-yuvarlaklık uyumuna girmiş olduğu Latin harfli örneklerden anlaşılmaktadır:

\begin{tabular}{|c|c|c|}
\hline \multicolumn{3}{|c|}{$\begin{array}{c}\text { SOVYET DÖNEMİ AZERBAYCAN } \\
\text { TÜRKÇESİ }\end{array}$} \\
\hline \multicolumn{3}{|c|}{ Arap Alfabesi } \\
\hline أو & $o+n u$ (göstar-) & $1925 / 1 / 8 / \mathrm{N} 6$ \\
\hline بونى. & $b u+n u$ (ilan et-) & $1925 / 1 / 8 / \mathrm{N} 6$ \\
\hline
\end{tabular}

\section{Latin Harfli Kommunist Gazetesi}

Kommunist gazetesinin Latin harfli metinlerinde belirtme durumu çekiminde de zamirlerden sonra $\{+n X\}$ eki kullanılmaya devam etmiştir:

\begin{tabular}{|c|l|c|}
\hline \multicolumn{3}{|c|}{ Latin Alfabesi } \\
\hline \multicolumn{3}{|c|}{ SOVYET DÖNEMİ AZERBAYCAN TÜRKÇESI } \\
\hline ont, & $o+n u(q o y-)$ & $1929 / 1 / 1 / \mathrm{N} 1$ \\
\hline bunu & $b u+n u$ (tasdik et-) & $1939 / 1 / 1 / \mathrm{N} 1$ \\
\hline
\end{tabular}

\section{Kiril Harfli Kommunist Gazetesi}

Kommunist gazetesinin Arap ve Latin harflilerde olduğu gibi Kiril harfli metinlerde de belirtme durumu çekiminde zamirlerden sonra $\{+n X\}$ eki kullanılmıştır:

\begin{tabular}{|c|c|c|}
\hline \multicolumn{3}{|c|}{$\begin{array}{c}\text { SOVYET DÖNEMI AZERBAYCAN } \\
\text { TÜRKÇESİ }\end{array}$} \\
\hline \multicolumn{3}{|c|}{ Kiril Alfabesi 1940-1991 } \\
\hline 6yHy & bu+nu (saxla-) & $1940 / 1 / 3 / \mathrm{N} 2$ \\
\hline oнy & $o+n u(o ̈ y r a n-)$ & $1940 / 1 / 1 / \mathrm{N} 1$ \\
\hline
\end{tabular}

Kommunist gazetesinden alınan metinlere göre zamirlerin belirtme durumu çekiminin Sovyet Dönemi Azerbaycan Türkçesinde Arap, Latin ve Kiril harfli tüm metinlerde $\{+n X\}$ ekiyle ile ölçünlü olarak yapıldığı ve bu çekimin aynı şekilde çağdaş Azerbaycan Türkçesinde de ölçünlüleştiği görülmektedir (Hüseynzadə, 2007; s. 50-51). Türkiye Türkçesinde de bu çekim aynı şekilde kullanılmaktadır.

Bu bilgilere göre, Sovyet Dönemi Azerbaycan Türkçesindeki zamirlerin belirtme durumu çekiminin hem Azerbaycan Türkçesinde hem de Türkiye Türkçesinde ortak olarak kullanıldığ anlaşılmaktadır: 


\begin{tabular}{|c|c|c|c|c|}
\hline \multicolumn{3}{|c|}{$\begin{array}{l}\text { SOVYET DÖNEMİ AZERBAYCAN TÜRKÇESİ } \\
\text { Zamir }+\{+n X\}\end{array}$} & \multirow{2}{*}{$\begin{array}{c}\text { AZERBAYCAN } \\
\text { TÜRKÇESİ } \\
21 . \text { yy. }\end{array}$} & \multirow{2}{*}{$\begin{array}{c}\begin{array}{c}\text { TÜRKİYE } \\
\text { TÜRKÇESİ }\end{array} \\
\text { 20-21.yy. }\end{array}$} \\
\hline Arap Alfabesi & Latin Alfabesi & Kiril Alfabesi & & \\
\hline \multicolumn{5}{|c|}{$o+n u$} \\
\hline & & ÖLÇÜNLÜ & & \\
\hline
\end{tabular}

\section{SONUÇ}

Bu çalışmada belirtme durumu çekimini gerçekleştiren eklerin Türk dili tarihindeki ses ve biçim özellikleri üzerinde durulmuş ve özellikle çekimin Azerbaycan Türkçesinin yazı dili olma sürecindeki değişimi Sovyet Dönemi Azerbaycan Türkçesinde resmî olarak 29 Ağustos 1919'dan itibaren yayımlanmaya başlayan Kommunist gazetesi örneklemi üzerinde incelenmiş ve şu sonuçlara ulaşılmıştır:

1. Belirtme durumu çekiminin, Kommunist gazetesindeki Arap harfli (29.08.1919-01.01.1929), Latin harfli (01.01.1929-01.01.1940) ve Kiril harfli (01.01.1940-27.08.1991) Azerbaycan Türkçesi metinlerinde farklı ses ve yazım özelliklerine sahip olduğu görülmektedir.

2. Türkçede belirtme durumu çekimi yalın isimler, iyelik ekli isimler ve zamirlerde görülmektedir. Bu çekim biçimlerinden yalın isimlerin çekiminde çekime giren ismin son sesine ve ses olaylarına (ses türemesi/yardımcı ses) göre farklı eklerin kullanıldığı, bunların Kommunist gazetesindeki Arap, Latin ve Kiril harfli metinlerdeki kullanım sıklıklarının da farklı olduğu görülmektedir. İyelik ekli isimlerin ve zamirlerin çekimi tüm metinlerde çă̆daş Azerbaycan Türkçesinde olduğu gibidir. Ancak bahsedilen farklılıklar sadece yalın isimlerin çekiminde görülmektedir:

Ünlüyle biten isimlerin $\{+(\mathrm{y}) \mathrm{X}\}$ ekiyle yapılan belirtme durumu çekimi Arap harfli metinlerde yaygın olarak kullanılmış, Latin harfli metinlerde çok azalmış, Kiril harfli metinlerde ise tamamen ortadan kalkmıştır.

Ünlüyle biten isimlerin $\{+n X\}$ ekiyle yapılan belirtme durumu çekimi, Arap harfli metinlerde çok az sayıda örnekte kullanılmış, Latin harfli metinlerde artmış, Kiril harfli metinlerde ise çok yaygınlaşmıştır. Çağdaş Azerbaycan Türkçesinde bu tür isimlerin çekimi $\{+n X\}$ ekiyle ölçünlüleşmiştir.

Ünsüzle biten isimlerin $\{+X\}$ ekiyle yapılan belirtme durumu çekimi; Arap, Latin ve Kiril harfli metinlerde ölçünlü olarak kullanılmış ve çă̆daş Azerbaycan Türkçesinde de bu kullanım devam etmiştir.

Ünsüzle biten isimlerin $\{+n X\}$ ekiyle yapılan belirtme durumu çekimi; Arap, Latin ve Kiril harfli metinlerde çok az örnekte kullanılmış, çağdaş Azerbaycan Türkçesinde de bu biçimiyle hiç kullanılmamış, bunun yerine $\{+X\}$ eki kullanılagelmiştir.

3. Bu çekim, çağdaş Azerbaycan Türkçesi ile Türkiye Türkçesindeki çekimlerle karşılaştırıldığında anlamlı ve ilgi çekici bir durum belirlenmiştir: Buna göre Sovyet Dönemi Azerbaycan Türkçesinin kullanıldığı Arap harfli Kommunist gazetesinde, sonu ünlüyle biten yalın 
isimlerin belirtme durumu çekiminin Türkiye Türkçesi ile ortak olduğu görülmektedir. Bu ortaklık 1940'lı yıllara kadar devam etmiş, sonrasında sonu ünlü ile biten isimlerin $\{+(y) X\}$ ekiyle çekimi Azerbaycan Türkçesinde ortadan kalkmış ve onun yerine, $\{+n X\}$ ekli çekim kullanılagelmiştir.

4. Belirtme durumu çekiminin Kommunist gazetesi özelinde Sovyet Dönemi Azerbaycan Türkçesi metinlerindeki durumunun alfabe farklılıkları ve Türkiye Türkçesiyle benzerliği açısından değerlendirildiğinde çok dikkat çekici bir durumla karşılaşılmaktadır: Sovyet Dönemi Azerbaycan Türkçesinin Arap alfabesiyle yazıldığı Kommunist gazetesi metinlerinde kullanılan dilin genel olarak dönemin Türkiye Türkçesine çok yakın olduğu görülmektedir. Belirtme çekimi başta olmak üzere birkaç çekimin ${ }^{61}$ ve yazımın o dönemde aynı olduğu, ancak sonrasında Azerbaycan'da birtakım değişikliklerin olduğu Kommunist gazetesinden izlenebilmektedir (Karataş, 2017). İşte bu değişiklikler alfabe farklılığı olan metinlerde görüldüğü için durum daha dikkat çekici bir hâl almaktadır.

1920'li yıllardaki yazı dilindeki bu ortaklı̆̆ın en önemli nedeni, o dönem Azerbaycan basınında görülen Türkiye ve Türkiye Türkçesi etkisidir. Dönemin "Sovyet" iktidarının resmî yayın organı olan Kommunist gazetesinde dahi Türkiye Türkçesi yazı dilinin etkisi açık bir biçimde görülebilmektedir. Bu etkinin kaynağı ise Azerbaycan basınında çalışanların birçoğunun Türkiye'de eğitim görmüş olması nedeniyle bu yazı dilini iyi bilmeleri ve yazılarında bu etkiden kurtulamamalarıdır. Bu dönemde bütün Türklerin aynı edebî dili (İstanbul Türkçesi) kullanmaları gerektiği düşüncesini savunan Füyuzat, Hayat gibi önemli dergilerin kadrosunda bulunan Türk aydınları da Türkiye Türkçesini örnek almışlar ve bu yazı dilini ortak olarak kullanmışlardır (Hacıyev, 2012, s. 325-331). Ancak Komünist Parti Merkezi Komitesi'nin yayın organı olan ve “Türkçe” adıyla yayımlanan Kommunist gazetesinde, özellikle ilk yıllarda (1920-1922) "halkın dili"yle yayımlandığı söylenerek Türkiye Türkçesine çok yakın bir dilin kullanılmış olması (Karataş, 2017, s. 864), bu ortaklığın sadece yazı dilinde olmadığını da göstermektedir.

5. Devlet ve toplumlar arası siyasi, kültürel ilişkilerin yazı dilini etkilemesi kaçınılmazdır. Ancak dildeki değişimlerin kullanılan alfabelere göre de şekillenmiş olması değişim sürecinin doğal olmadığını göstermektedir. Çünkü alfabe veya daha genel bir ifadeyle yazı sistemlerinin dillerin değişimiyle doğrudan bir ilişkisi yoktur. Harfler sadece o dildeki sesbirimleri (fonem) gösteren birer işarettir. Tarihî dönemlerde dillerde gerçekleşen değişimler ise bu işaretler veya yazım aracılığıyla öğrenilebilmektedir. Bu durum belirtme durumu çekimi örneğinde Kommunist gazetesinin yayın sürecindeki metinlerde açık bir biçimde görülebilmektedir.

Çarlık Dönemi'nde, Nikolay İvonoviç İlminskiy (1822-1891) ile başlayan, SSCB'de devam eden Türk halklarının konuşmalarındaki ses farklılıklarını ayrı Kiril harfleriyle yazıya geçirerek her konuşma dilini önce bir yazılı dile, sonra bir farklı yazı diline, en sonunda da farklı bir adla

\footnotetext{
${ }^{61}$ TT$^{\prime}$ de şimdiki zaman çekimi için 16. yüzyıldan beri \{-yor\} eki kullanılırken Azerbaycan Türkçesinde, aynı işlev için Eski Anadolu Türkçesinde geniş zaman çekiminde kullanılan dar ünlülü \{-Ir\} eki kullanılmaktadır. Kommunist gazetesinin Arap harfli sayılarının tamamında şimdiki zaman çekimi için -yor eki kullanılmıştır. İlgi çekici bir şekilde Latin harfli metinlerde bu ekin kullanımı gittikçe azalmış, \{-Ir\}'ın kullanımı artmıştır. Latin alfabesine geçiş dönemindeki çift alfabeli çıkan sayılarda ise Arap harfli yazılarda \{-yor\}, Latin harfli yazılarda kullanılmıştır. 1929'dan sonra ise \{-yor\} eki tamamen kullanımdan düşmüştür (Karataş, 2017, s. 870).

$\{-\operatorname{Ir}\}$ birlikte
} 
ayrı bir "dil"e dönüştürülmesi amacını taşıyan politikalar, Türk yazı dilleri (lehçeler) arasındaki farkların büyümesine yol açmıştır (Gökdağ, 2002, s. 94-97). Böylece ortada "Türk" de ortak bir “Türkçe” de kalmamıştır.

SSCB'nin ilk döneminde, Lenin'in sıkça "milletlerin kendi geleceklerini tayin etme hakları" ve özerklik, millî edebiyat, millî kültür konularıyla ilgili sözde haklardan söz etmesine rağmen Rus dilini ve kültürünü zirveye taşıma arzusunu, Rus olmayan milletlerin zihinlerine yavaş yavaş yerleştirmeye çalıştığı onun “SSCB'nin bütün işçilerini” Rusya'nın ve Rusçanın çatısı altına alarak kendi kurallarına göre yönetmek amacında olduğunu dönem içerisindeki tüm uygulamalar ortaya koymuştur (Aliyeva, 2005, s. 57). İşte bu “dil planlaması" kapsamındaki uygulamalar Latin harfli metinlerde görülmeye başlamış, Kiril alfabesine geçildiği dönemden itibaren ise süreç tam anlamiyla bir "asimilasyon" a dönüşmüştür.

Türkiye Türkçesine en fazla bir "ağız" kadar uzak olan, aynı adla (Türkçe), aynı alfabeyle (Arap) yazılan Azerbaycan Türkçesindeki farklılıklar, Latin harfli metinlerde kayda geçmeye başlamış, birkaç yıl aynı gazetede ikili kullanımlar görülmüş, ancak 01.01.1929 tarihinde tamamen Latin harflerine geçildiğinde bahsedilen farklılıklar artık bir tutarlılık sergilemeye başlamıştır. 01.01.1940'ta Kiril'e geçildikten sonra ise artık adı "Türkçe" değil, "Azerbaycan dili" olan Azerbaycan Türkçesinde bu farklıklar ölçünlü bir dil unsuru olmuşlardır. İşte bu süreçte uygulanan bu dil planlaması politikası, ortak bir Türkçeden adı ve alfabesi farklı iki yazı dili ortaya çıkarmıştır.

20. yüzyılın başında beri devam eden yazım konusundaki tartışmalarda, dönemin önde gelen aydınlarının halkın söyleyişinin ölçüt alınması fikri ağırlık kazanınca tartışma alfabeye odaklanmış ve Azerbaycanlı Türk aydınları, Arap alfabesinde Türkçenin yazımını tartışırken sorunun yazım değil alfabe olduğunda uzlaşmışlardır. Böylece Arap alfabesi tartışılmaya başlamıştır. 1926'da Bakü'de düzenlenen I. Türkoloji Kongresi sonrasında bu süreç hızlanmış ve Latin alfabesine geçilmiştir. Halkın söyleyişinin ölçüt alınması fikriyle birlikte ağız özellikleri yeni harfler aracılı̆̆ıyla yazıya geçirilmeye başlamış, Arap alfabesiyle olan tarihî geleneksel yazım ilkeleri bir kenara bırakılmıştır (Aliyeva, 2005, s. 169-275). Bu durum, Türkiye ile Azerbaycan'ın ortak yazı dili geleneğinden de hızla uzaklaşılmasına neden olmuştur.

Bahsedilen sürecin somut bir göstergesi olarak belirtme durumu çekimi örnek verilebilir. Arap alfabeli metinlerde masələ $+y+i$, muhazir $+y+i$, müsamir $+y+i, k \partial l i m \partial+y+i$, tiyatro $+y+u$, qaid $+y+i$ biçiminde olan çekim, Latin harfli metinlerde tiyatro+nu, masələ+ni, muharizə+ni, müsamirə+ni, kəlimə+ni, qaidə+ni biçiminde kullanılmaya başlamış, 1940’lı yıllarda bu biçim ölçünlüleşmiştir. Böylece yazı dilindeki bir ortaklık sona ermiştir. Bu durum iki alfabeli metinlerin yayımlandığ sayılarda, hatta aynı sayfada dahi böyledir: 


\begin{tabular}{|c|c|c|}
\hline Arap Harfli Metin & Latin Harfli Metin & Kiril Harfli Metin \\
\hline $\mathbf{C}^{\mathbf{4}} \rightarrow$ masala $+y+i 62$ & tijatrony tiyatro $+n u^{63}$ & 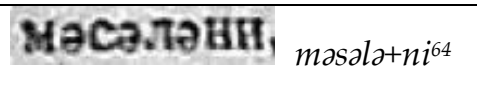 \\
\hline 346 kalima $+y+i^{65}$ & musamirenl, müsamira+ni66 & мүбаркзани mübarizə+ni \\
\hline u.dis qaid $+y+i^{67}$ & muhazlronl. muhazira+ni68 & Вәзифанแ \\
\hline
\end{tabular}

$\mathrm{Bu}$ uygulamaların Latin alfabesine geçilmesiyle birlikte yapılmaya başlaması ise tamamen ses-harf ilişkisiyle ilgili bir konudur. Arap alfabesi, Türkçenin seslerini yansıtma konusundaki yetersizliği, farklı seslerin tek harfle yazılma özelliği gibi birtakım sorunlara neden olsa da bahsedilen özelliklere bağlı olarak Türk ağılarındaki ses farklılıklarını örtmesi, gizlemesi açısından, o dönem ve o coğrafyada ortak Türkçe için bir imkân olarak görülmüştür. Örneğin, toprak+l, ev $+i$, çocuk+u, üzüm+ü sözcüklerindeki belirtme durumu eki Arap alfabesiyle sadece ye harfi (s) ile yazılırken Latin alfabesinde her biri farklı bir harfle $(\imath, i, u, \ddot{u})$ yazılır. İşte bu durum farklı ağız özelliklerine sahip olan Türk halklarının en azından yazı dilinde bir ortaklığa sahip olmasını sağlamıştır. İsmail Gaspıralı'nın (1851-1914), “ortak dil” düşüncesinin Arap alfabesine dayanmasinin da temel nedeni budur.

Latin alfabesine geçildikten sonra yeni yazı sisteminin sesleri karşılama özelliği, Türk ağızlarını birbirinden ayırmak için kullanılmıştır. Böylece Arap alfabesinin sağladığı görüntü, Latin alfabesine geçirildikten sonra ortadan kalkmış ve ağız düzeyinde görülebilecek farklılıklar belirginleştirilmiştir. Latin alfabesiyle başlayan bu süreç, özellikle Stalin'in uyguladığı sert politikaların da bir yansıması olarak Kiril alfabesinde çok daha açık bir şekilde yürütülmüş ve artık Türkiye Türkçesi ile Azerbaycan Türkçesi belirgin bir şekilde ayrılmıştır.

Sonuç olarak, Kommunist gazetesi örneklemi üzerinde Sovyet Dönemi Azerbaycan Türkçesindeki belirtme durumu çekiminin incelendiği bu çalışmada; bu çekimin yaklaşık 20 yıllık süre içerisinde (1920-1940) farklılıklar gösterdiği belirlenmiştir. Arap, Latin ve Kiril harfli metinlere göre farklılık göstermesi, konunun sadece dilin doğasında bulunan doğal bir değişim olmadığını, burada "politik" bir müdahalenin gerçekleşmiş olabileceğini düşündürmüştür. Yapılan inceleme ve değerlendirme ile SSCB'de, özellikle Stalin döneminde uygulanan politikalar göz önüne alındığında, belirtme durumu çekiminde görüldüğü gibi uygulamaya konan bu değişimlerin Azerbaycan ile Türkiye Türklüğünün kullandığı ortak yazı dilini ayırmaya yönelik bilinçli bir "dil planlaması politikası" olduğu düşüncesine varılmıştır.

\footnotetext{
62 1926/1/2/N1

63 1926/1/2/N1

$641940 / 1 / 3 / N 2$

${ }_{65} 1926 / 1 / 4 / \mathrm{N} 3$

${ }^{66} 1926 / 1 / 2 / \mathrm{N} 1$

${ }_{67} 1926 / 1 / 3 / \mathrm{N} 2$

68 1926/1/2/N1

${ }^{69} 1940 / 1 / 3 / \mathrm{N} 2$
} 


\section{KAYNAKLAR}

Akalın Şükrü Haluk (2013). “Türk Dünyasında Dil”. Yeni Türkiye Dergisi. Türk Dünyası Özel Sayısı I. Stratejik Araştırma Merkezi Yayınları. S. 53 (Temmuz-Ağustos). s. 358-379.

Akar, Ali (2018). Oğuzların Dili Eski Anadolu Türkçesine Giriş. İstanbul: Ötüken Yayınları.

Aliyeva, Gönül (2005). SSCB Döneminde Azerbaycan'da Dil Plânlaması. Yayımlanmamış Doktora Tezi.

Ankara: Ankara Üniversitesi.

Alkaya, Buran vd. (2017). Çă̆daş Türk Yazı Dilleri 1. Ankara: Akçă̆ Yayınları.

Argunşah, Mustafa ve Güler, Galip (2015). Codex Cumanicus. İstanbul: Kesit Yayınları.

Argunşah, Mustafa ve Sağol Yüksekkaya, Gülden (2017). Karahanlıca Harezmce Kıpçakça Dersleri.

İstanbul: Kesit Yayınları.

Argunşah, Mustafa (2020). Çă̆atay Türkçesi. İstanbul: Kesit Yayınları.

Akpınar, Yavuz (2001). “Gaspıralı'nın Türk Diline Bakışı”. Türk Dünyası Dil ve Edebiyat Dergisi. Türk Dil

Kurumu. S. 12/1, s. 385-408.

Başdaş, Cahit (2008). “Türkçede İyelik-Yükleme Sorunu Dede Korkut Örneği”. Turkish Studies (International Periodical For The Languages, Literature and History of Turkish or Turkic). S. 3/1, s. 6-13.

Başdaş, Cahit (2009). “Orhun Abidelerinde İyelik, Belirtme ve Yükleme Hâli”. Turkish Studies. Volume 4/8. Fall s. 623-643.

Başdaş, Cahit (2011). “Doğu Anadolu Ağızlarında Hâl Kavramı Taşıyan İyelikli Yapılar”, Turkish Studies. Volume 6/1. Winter s. 739-746.

Bulak, Şahap ve Ulutaş, İsmail (2017). “Zamir N'si Üzerine Değerlendirmeler”. Akademik Bakış Dergisi. S. 60 (Mart-Nisan). s. 452-460.

Bulat, Ufa (Der.) (1925). Piyoner Yırźarı. Başkiniga.

Buran, Ahmet ve Alkaya, Ercan (2014). Çă̆daş Türk Yazı Dilleri 3. Ankara: Akçağ Yayınları.

Buran, Ahmet vd. (2014). Çă̆ğaş Türk Yazı Dilleri 4. Ankara: Akçă̆ Yayınları.

Buran, Ahmet ve Alkaya, Ercan (2014). Çağdaş Türk Yazı Dilleri 2. Ankara: Akçağ Yayınları.

Coşkun, Mustafa Volkan (2014). Özbek Türkçesi Grameri. Ankara: Türk Dil Kurumu Yayınları.

Develi, Hayati (2014). Osmanlı Türkçesi Grameri. İstanbul: Kesit Yayınları.

Dilaçar, Agop (1957). “Türk Lehçelerinin Meydana Gelişinde Genel Temayüllerin Koyulaşması ve Körlenmesi", TDAYD-BELLETEN, Ankara, TDK Yayınları.

Doğan, Talip (2012). “İan (Azerbaycan) Türk Ağılarında Yükleme Hâli Ekleri”. Turkish Studies (International Periodical For The Languages, Literature and History of Turkish or Turkic). S. 7/1 K1ş. S. 915-933.

Doğan, Oğuz ve Koç, Kenan (2013). Kazak Türkçesi Grameri. İstanbul: IQ Kültür Sanat Yayıncilık.

Eckmann, Janos (2014). Harezm, Kıpçak ve Çağatay Türkçesi Üzerine Araştırmalar. Hz. Osman Fikri Sertkaya. Ankara: Türk Dil Kurumu Yayınları.

Eckmann, Janos (2017). Çă̆atayca El Kitabı. Çev. Günay Karaağaç. Ankara: Türk Dil Kurumu Yayınları.

Ercilasun, Ahmet Bican (1996). “Batı Türkçesinin Doğuşu”. Uluslararası Türk Dili Kongresi 1988. Ankara. TDK Yayınları. s. 39-45.

Ercilasun, Ahmet Bican (2007). Makaleler. Hz. Ekrem Arıkoğlu. Ankara: Akçağ Yayınları.

Ercilasun, Ahmet Bican (2012). Türk Lehçeleri Grameri. Ankara: Akçă̆ Yayınları.

Ercilasun, Ahmet Bican (2014). Örneklerle Bugünkü Türk Alfabeleri. Ankara: Akçağ Yayınları.

Ercilasun, Ahmet Bican (2017). Başlangıçtan Yirminci Yüzyıla Türk Dili Tarihi. Ankara: Akçă̆ Yayınları. 
Erdal, Marcel (2004). A Grammar of Old Turkic. Leiden: Boston.

Erdem Uçar, Filiz Meltem (2015). Gedâyî Dîvânı (İnceleme, Metin, Tıpkıbasım). Ankara: Gazi Kitabevi. Ergin, Muharrem (1981). Azeri Türkçesi. İstanbul: İstanbul Üniversitesi Edebiyat Fakültesi Yayınları.

Ergin, Muharrem (1986). Türk Dil Bilgisi. İstanbul: Bayrak Yayınları.

Ergin, Muharrem (2013). Türk Dil Bilgisi. İstanbul: Bayrak Yayınları.

Ergin, Muharrem (2016). Orhun Abideleri. İstanbul: Bayrak Yayınları.

Ersoy, Feyzi (2018). Çuvaş Türkçesi, Türk Dilinin Uzak Lehçeleri. Ankara: Akçağ Yayınları.

Ozizov, Elbrus (1999). Azərbaycan Dilinin Tarihi Dialektoloqiyası. Bakı: Bakı Ünivərsitəti Neşriyyatı.

Gabain, Annemarie von (2007). Eski Türkçenin Grameri. Çev. Mehmet Akalın. Ankara: Türk Dil Kurumu Yayınları.

Gökdağ, Bilgehan Atsız (2002). “Dil Planlaması Bağlamında Türk Yazı Dillerinin Görünümü”, Türkler Ansiklopedisi, Ankara, Yeni Türkiye Yayınları, C.19, s. 92-125.

Gülsevin, Gürer (2007). Eski Anadolu Türkçesinde Ekler. Ankara: TDK Yayınları.

Gülsevin, Gürer (1997). Eski Anadolu Türkçesinde Ekler. Ankara: Türk Dil Kurumu Yayınları.

Gülsevin, Selma (2010), Günümüz Karay Türkçesi (Giriş-Dil Özellikle-Metinler-Söz Dizini) ve Türk Lehçeleri Arasındaki Yeri. Doktora Tezi, İzmir: Ege Üniversitesi.

Gürdoy-Naskali, Emine (1997). Türk Dünyası Gramer Terimleri Kılavuzu. Ankara: Türk Dil Kurumu Yayınları.

Hacıeminoğlu, Necmettin (1968). Kutb'un Husrev ü Şirin'i ve Hususiyetleri. İstanbul: Edebiyat Fakültesi Matbaasi.

Hacıyev, T. İ., (2012). Azerbaycan Edebi Dilinin Tarixi 2. Bakı: Elm ve Tehsil.

Hüseynzadə, Muxtar (2007). Müasir Azərbaycan Dili Morfologiya. Bakı: Lüğet ve Ensiklopediyalar.

İmer, Kamile vd. (2011). Dilbilim Sözlüğ̈̈̈. İstanbul: Boğaziçi Üniversitesi Yayınevi.

Karaağaç, Günay (2013). Türkçenin Dil Bilgisi. Ankara: Akçağ Yayınları.

Karamanlıŏ̆lu, Ali Fehmi (1989). Gülistan Tercümesi. Ankara: Türk Tarih Kurumu Basımevi.

Karataş, Mustafa (2019). Her Yönüyle Türk Dili. Kayseri: Kimlik Yayınları.

Karataş, Mustafa (2020). Türkçe ve Felsefe Terimleri. Ankara: Pegem Akademi Yayınları.

Karataş, Mustafa (2018). “Azerbaycan Türklerinin Konuştuğu Dilin Ad1 Nedir?”. Türkiye ile Türk Dünyası Arasında Bir Köprü Yavuz Akpınar. Ankara: Bengü Yayınları. s. 425-466.

Karataş, Mustafa (2017). “Sovyet Dönemi Azerbaycan Matbuatında Kommunist Gazetesinin Dili”. 6. Uluslararası Türkiyat Araştırmaları Sempozyumu: 100. Yılında Sovyet İhtilali ve Türk Dünyası. Ankara: Hacettepe Üniversitesi Türkiyat Araştırmaları Enstitüsü. s. 857-874.

Karataş, Mustafa (2010). “Azerbaycan Türkçesinin Fuzuli'deki İzleri”. Turkish Studies - Türkoloji Araştırma Dergisi. C. 5/1. s. 525-555.

Kartallığlu, Yavuz (2008). “Osmanlı Türkçesindeki Ekler Dudak Uyumuna Göre Nasıl Okunmalıdır?”. Turkish Studies. C. 3/6. s.449-470.

Kartallığlu, Yavuz (2011). Klasik Osmanlı Türkçesinde Eklerin Ses Düzeni (16, 17 ve 18. Yüzyıllar). Ankara: Türk Dil Kurumu Yayınları.

Kerimoğlu, Caner (2007). “Orhun Abidelerinde 3. Kişi İyelik Ekinden Sonra Yükleme Hâli Eki Kullanıldı mı?". Turkish Studies. Volume 2/3. Summer, s. 322-331.

Kasapoğlu Çengel, Hülya (2017). Kırģı Türkçesi Grameri (Ses ve Şekil Bilgisi). Ankara: Türk Dil Kurumu Yayınlar. 
Kazımov, Q, Ş. (2010). Müasir Azerbaycan Dili. Bakı: Elm ve Tehsil.

Kılıç, Ensar; Serpil Ersöz (2020). "Zamir /N/'sinin Türkçedeki Fonemorfolojik Gelişimi”. Uludağ Üniversitesi Fen-Edebiyat Fakültesi Sosyal Bilimler Dergisi, C. 21, S. 38, s. 565-606.

Kirişçioğlu, Mehmet Fatih (2018). Saha/Yakut Türkçesi, Türk Dilinin Uzak Lehçeleri. Ankara: Akçağ Yayınları.

Koç, Fatma (2020). “Karışık Dilli Eserlerin Fonetik Özellikleri Üzerine Bir Değerlendirme”. Milli Kültür Araştırma Dergisi. (4/1). s. 55-68.

Korkmaz, Zeynep (1992). Gramer Terimleri Sözlüğü. Ankara: Türk Dil Kurumu Yayınları.

Korkmaz, Zeynep (2017). Türkiye Türkçesi Grameri Şekil Bilgisi. Ankara: Türk Dili Kurumları Yayınları.

Mansuroğlu, Mecdut (1949). “Türkçede Zamir Çekimi”. İstanbul Üniversitesi Edebiyat Fakültesi Türk Dili ve Edebiyatı Dergisi. C. 3, S. 3-4, s. 501-518.

Məhərrəmov, E.; Məhərrəmli, A. (2009). Xalq Qazeti, Yaranması ve İnkişafı Tarixinden, Azerbaycan Milli Akademiyası A. A. Bakıxanov adına Tarix İnstitutu, Bakı: Elm ve Tehsil.

Mirzəzadə, H. (1962). Azerbaycan Dilinin Tarihi Morfoloqiyası. Bakı: Azertedrisneşr.

Mirzəzadə, H. (1990). Azerbaycan Dilinin Tarihi Grammatikası. Bakı: Azerbaycan Üniversiteti Neşriyyatı.

Ölmez, Mehmet (2012). Orhon-Uygur Hanlığı Dönemi Moğolistan'daki Eski Türk Yazıtları, MetinÇeviri-Sözlük. Ankara: Bilgesu.

Ölmez, Mehmet (2017). Köktürkçe ve Eski Uygurca Dersleri. İstanbul: Kesit Yayınları.

Öner, Mustafa (1998). Bugünkü Kıpçak Türkçesi. Ankara: Türk Dil Kurumu Yayınları.

Öztürk, Rıdvan (2015). Köktürkçe El Kitabı. Konya: Palet Yayınları.

Radlov, Vasily Vasilyeviç, Sergey Efimoviç Malov, Suvarṇaprabhāsa (Sutra zolotogo bleska). Tekst' uygurskoy redaktsii. I-IV. Bibliotheca Buddhica: XVII, St. Petersburg 1913-1917. [I-II: 1913; IIIIV: 1914; V-VI: 1915; VII-VIII: 1917].

Seỳtäkov, Beki (1972). Bedirkent. Aşkabat: Türkmenistan Neşiryatı.

Süleymanlı, Ebulfez (2006). Milletleşme Sürecinde Azerbaycan Türkleri. İstanbul: Ötüken Yayınları.

Şahin, Hatice (2018). Eski Anadolu Türkçesi. Ankara: Akçă̆ Yayınları.

Tanrıverdi, Ozizxan (2014). Azərbaycan Dilinin Tarixi Qrammatikası. Elm və Təhsil: Bakı.

Tekin, Talat (2003). “Üçüncü Kişi İyelik Eki Üzerine”. Makaleler I: Altayistik. Hz. Emine Yılmaz, Nurettin Demir. Ankara: TDK Yayınları.

Tekin, Talat (2013). “Türkçe'de Kaynaştırma Sesleri”. Makaleler III: Çă̆daş Türk Dilleri. Hz. Emine Yılmaz, Nurettin Demir. Ankara. TDK Yayınları.

Tekin, Talat (2016). Orhon Türkçesi Grameri. Ankara: Türk Dil Kurumu Yayınları.

Topaloğlu, Ahmet (1989). Dil Bilgisi Terimleri Sözlüğ̈̈. İstanbul: Ötüken Yayınevi.

Uğurlu, Mustafa (2011). “Oğuzca ve Anadolu Merkezli Oğuz Türkçesi”. Turkish Studies (International Periodical For The Languages, Literature and History of Turkish or Turkic). Ankara. C. 6/1, s. 123-156.

Uzman, Mehmet, Türkistan'da Dil Tartışmaları Özbekçe'nin İcat Edilişi (1917-1940), Yayımlanmamış Doktora Tezi. Ankara: Gazi Üniversitesi.

Uzun, Nadir Engin (2006). Biçimbilim Temel Kavramlar. Papatya Yayıncılık: İstanbul.

Yalçın, Süleyman Kaan (2018). Azerbaycan Türkçesi Grameri. İstanbul: Kesit Yayınları.

https://til.im/tr-qm/knigi/literatura-na-kumykskom-yazyke/men-oktemmen?gesek=1 (erişim tarihi: 16.08.2021) 
http://kumukia.ru/\%D0\%BD\%D0\%BE\%D0\%B2\%D1\%8B\%D0\%B9\%D1\%80\%D0\%B5\%D1\%81\%D1\%83\% D1\%80\%D1\%814.html\#cf (erişim tarihi: 16.08.2021).

Kommunist Gazetesi Sayılar1: 1921/2/11/N9, 1921/2/14/N11, 1922/8/1/N170, 1924/11/4/N246, 1925/1/8/N6， 1926/1/2/N1， 1926/1/3/N2， 1926/1/4/N3， 1928/12/28/N302， 1929/1/1/N1， 1930/1/15/N12, 1939/1/1/N1, 1939/3/3/N50, 1940/1/1/N1, 1940/1/3/N2, 1940/1/4/N3, 1940/5/1/N100, $1940 / 8 / 29 / \mathrm{N} 50$

\section{KISALTMALAR}

AY Altun Yaruk

D Doğu

G Güney

KT Kü/öl Tègin

RM Radlov-Malov 
